\title{
Slaughterhouses and producers of Animal By-products in the Nordic Countries
}

10 Nordic Council of Ministers 



\section{Slaughterhouses and producers of Animal By-products in the Nordic Countries}

Ole Pontoppidan and Mirko Miseljic

TemaNord 2016:551 
Slaughterhouses and producers of Animal By-products in the Nordic Countries Ole Pontoppidan and Mirko Miseljic

ISBN 978-92-893-4744-0 (PRINT)

ISBN 978-92-893-4745-7 (PDF)

ISBN 978-92-893-4746-4 (EPUB)

http://dx.doi.org/10.6027/TN2016-551

TemaNord 2016:551

ISSN 0908-6692

Standard: PDF/UA-1

ISO 14289-1

(C) Nordic Council of Ministers 2016

Layout: NMR

Print: Rosendahls-Schultz Grafisk

Printed in Denmark

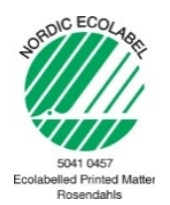

Although the Nordic Council of Ministers funded this publication, the contents do not necessarily reflect its views, policies or recommendations.

\section{Nordic co-operation}

Nordic co-operation is one of the world's most extensive forms of regional collaboration, involving Denmark, Finland, Iceland, Norway, Sweden, the Faroe Islands, Greenland, and Åland.

Nordic co-operation has firm traditions in politics, the economy, and culture. It plays an important role in European and international collaboration, and aims at creating a strong Nordic community in a strong Europe.

Nordic co-operation seeks to safeguard Nordic and regional interests and principles in the global community. Shared Nordic values help the region solidify its position as one of the world's most innovative and competitive. 


\section{Contents}

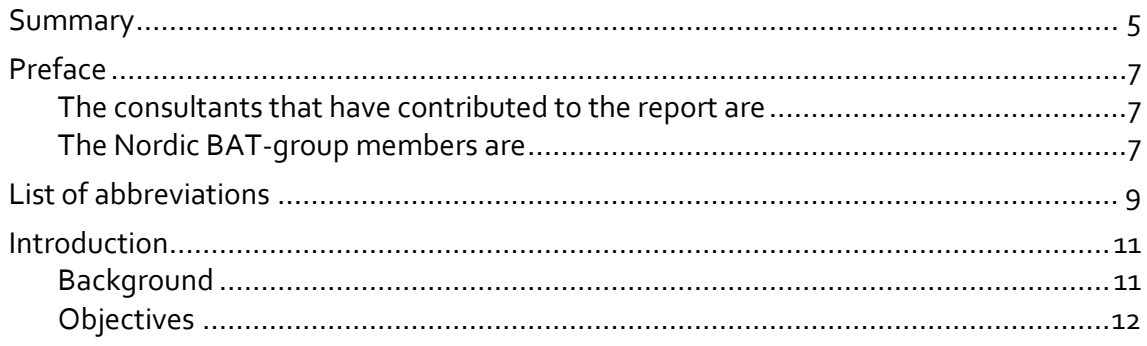

1. Overview of the Nordic sector - processes and techniques ..............................13

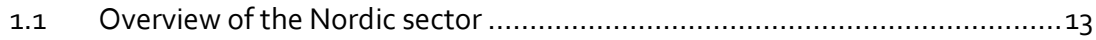

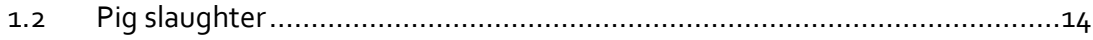

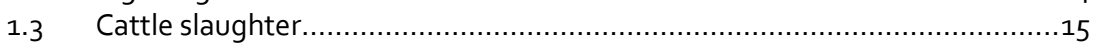

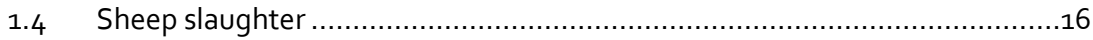

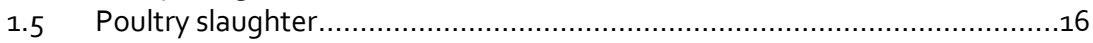

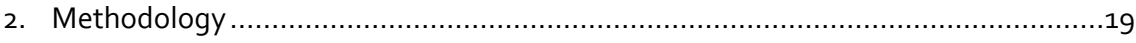

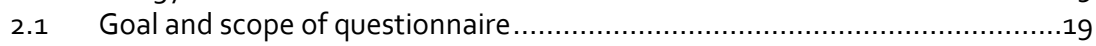

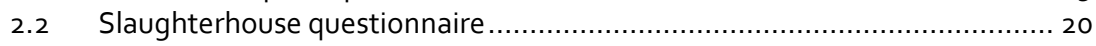

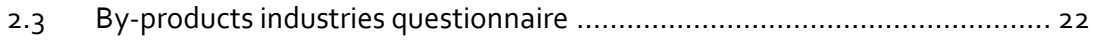

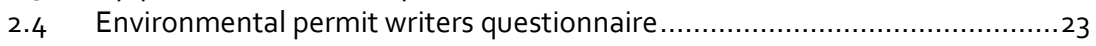

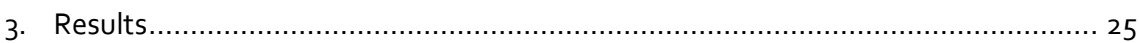

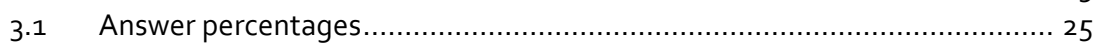

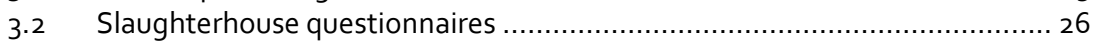

3.3 By-products installation questionnaires ..............................................

3.4 Environmental permit writer questionnaires.......................................... 40

3.5 Slaughterhouse processes, impacts and measures.................................. 42

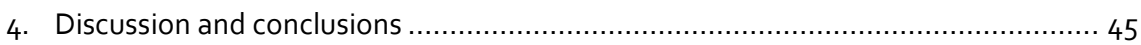

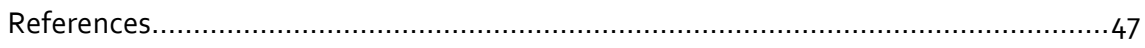

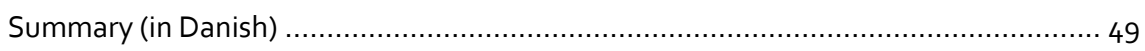

Appendix 1: Slaughterhouse BAT questionnaire results ....................................... 51

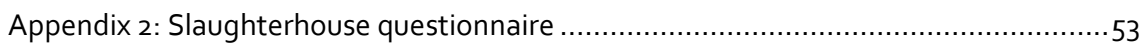

Appendix 3: By-products installation questionnaire .............................................63

Appendix 4: Environmental permit writer questionnaire .........................................69 69

Appendix 5: Environmental permit writers answers ............................................ 73 



\section{Summary}

The Nordic Council of Ministers, the BAT group under Working Group for Sustainable Consumption and Production, has requested the Danish Meat Research Institute (DMRI) for consultancy aid and to deliver a review report on Best Available Techniques (BAT) for slaughterhouses and producers of animal by-products in relation to the Nordic industry. The report is based on research by questionnaires to several companies and a few competent authorities combined with the background knowledge of DMRI. The questionnaires to companies were answered by slaughterhouses and animal by-product installations from Denmark, Sweden, Norway and Finland, that are subject to the BREF. They were asked about general details in their current production patterns, emissions and resource accounting, relating to potentially dubious BATs (BATs that may be difficult to follow - based on own experience), and stand according proposed ideas for future BATs (DMRI proposed BAT ideas based on own experience and expertise). Also, a few Nordic environmental permit writers/inspectors were asked about the key environmental indicators that they apply when issuing permits or monitoring slaughterhouses and animal by-products installations. The results can be used by operators, consultants and environmental authorities and are intended to be used in relation to the input from the Nordic countries for the upcoming EU process under the Industrial Emissions Directive (IED) for preparing the new BREF for Slaughterhouses and Animal By-product Industries.

The questionnaire answers were gathered from 33 slaughterhouses, 6 byproduct installations and 5 environmental permit writers/inspectors. Among these, the tendency was that large slaughterhouse operations tend to use mechanical and automated (use of robot technology) technological approaches while small operations use mechanical, manual and automated approaches. Automated approaches need a higher resource consumption (e.g. through electricity), but the environmental impact considerations in this case must also include benefits in terms of more product produced.

According to the existing BREF (European Commission 2005), the environmental issues for slaughterhouses and by-product installations were in general water consumption, emission of high organic strength liquids to water (containing fats and blood), energy consumption (mainly due to water heating for cleaning, refrigeration, drying of by-products), treatment (incl. destruction) of TSE infected materials and odour. Emission levels were defined as achievable 
amounts (if BATs are applied) for wastewater emissions (after on-site or e.g. municipal wastewater treatment) and for incineration of animal by-products. Currently, the survey respondents in this study mainly account their utility consumption, wastewater and detergents in a total manner. However, allocation of these according to slaughter and by-products processing is currently not possible, according to the asked slaughterhouses.

In general, the slaughterhouses comply with difficult BATs (ones that may be dubious to their operation), unless they are irrelevant for their operation. Our proposal for new BATs (11 for slaughterhouses \& 6 for by-products installations), which are made on the basis of DMRIs own expertise judgement and experience from the slaughterhouse and animal by-product sector. Among these, a more holistic environmental thinking was proposed to set the basis for fair environmental benchmarking in the future. This means that more processing and improved utilisation of e.g. by-products from a cow (for e.g. human consumption) could justify a higher energy consumption. This could result in environmental benefits and perhaps economic gains for the installations. However, one needs to be aware of potential burden shifting of environmental impacts across the life cycle and across different media (also addressed in cross media effects BREF), when accounting or introducing BAT demands. Potential future introduction of binding emission demands (AELs) need to consider the needed increased processing when aiming towards a better utilisation of animal by-products.

According to the contacted Nordic environmental permit writers/inspectors there is a focus on wastewater quality, combustion gases, energy and water consumption as well as noise and odour. This is in line with the slaughterhouse and by-product installations' approach to account total emissions. In relation, slaughterhouse processes contributing to environmental impacts and measures to lower these were described. 


\section{Preface}

The Nordic Council of Ministers, the BAT-group under Working Group for Sustainable Consumption and Production, has awarded Danish Meat Research Institute (DMRI) for consultancy aid and to deliver a review report on Best Available Techniques (BAT) for slaughterhouses and producers of animal byproducts in relation to the Nordic industry. The intention with the report is to use it in the first step of the upcoming EU revision of a new slaughterhouse and animal by-products BAT-reference document (BREF).

The project is based on questionnaires in which slaughterhouses and animal by-products industries from Denmark, Sweden, Norway and Finland were asked about general details in their current production patterns, emissions and resource accounting, relation to potentially dubious BATs (BATs that may be difficult to follow, based on DMRI industry experience), and stand according DMRI proposed ideas for future BATs (based on DMRI industry experience and expertise). The results can be used by operators, consultants and environmental authorities and are intended to be used in relation to the input from the Nordic countries to the upcoming EU process under the Industrial Emissions Directive (IED) for preparing the BREF for Slaughterhouses and Animal By-products industries, which is expected to start in 2017.

\section{Consultants that have contributed to the report}

- Mirko Miseljic, DMRI.

- Ole Pontoppidan, DMRI.

\section{Nordic BAT-group members}

- Anne Kathrine Arnesen, Norwegian Environment Agency.

- Birgitte Holm Christensen (Project contact person), Danish Environmental Protection Agency.

- Kaj Forsius, Finnish Environment Institute (Chairman).

- Maria Enroth, Swedish Environmental Protection Agency.

- Lena Ziskason, Environment Agency of Faroe Islands. 
- Susanne Särs, Åland Environmental and Health Protection Authority.

- Halla Einarsdóttir, The Environment Agency of Iceland.

The four first mentioned members supervised the work. 


\section{List of abbreviations}

- AEL: Associated Emission Levels.

- BAT: Best Available Techniques.

- BAT Group: A sub-group under Working Group for Sustainable Consumption and Production.

- BREF document: Best Available Techniques Reference Document: Slaughterhouses and Animal by-products Industries.

- IED: Industrial Emissions Directive.

- IPPC: Integrated Pollution Prevention and Control.

- SRM: Specified Risk Materials.

- TSE: Transmissible Spongiform Encephalopathy. 



\section{Introduction}

\section{Background}

In line with the global population growth and the intrinsic human needs there is an increasing pressure on the environment in which we live. Thus, there is an industrialised need for processing large amounts of resources. In this relation, in 1996, the European Member States introduced the EU Directive on Industrial Pollution Prevention and Control (IPPC). The purpose was to achieve integrated prevention and control of emissions to air, water and soil, generation of waste, use of raw materials, energy efficiency, noise, prevention of accidents and restoration of sites upon closure of facility (Daddi et al. 2012). IPPC is important for all industrial installations under its scope, as these have to acquire licences where they oblige to the IPPC environmental regulations (Daddi et al. 2012). As a function of this, the Best Available Techniques Reference documents (BREFs) were published to guide industrial sectors regarding which tools to use to meet the requirements of the IPPC Directive. This included descriptions of the techniques and processes used for different sectors, current emission and consumption levels, and techniques of how to determine Best Available Techniques (BAT) and emerging techniques. In 2011, the Industrial Emissions Directive (IED) was introduced as a replacement of IPPC. The directive defined BAT as the most effective and advanced stage in the development of activities and operations, which indicates technique suitability in relation to reduction of emissions (according to limits) and overall environmental impacts. The BAT abbreviation means (European Parliament and Council 2010):

- "Best" means the most effective in terms of achieving a high level of protection of the whole environment.

- "Available" is defined as what is currently accessible, both economic and technically, for an installation.

- "Techniques" consider technology and also the way the installation is designed, built, maintained, operated and decommissioned.

BATs are reference information for the permitting authorities in their approach to set the permit conditions. These are described in the BAT-Reference documents (BREF) that in particular describe the applied techniques, present emissions and consumption levels, techniques considered for the determination 
of best available technique, and BAT conclusions. The BAT conclusions describe the agreed upon BATs, their description, level of applicability, site remediation, emission levels, and associated monitoring and consumption levels (Salminen et al. 2014). It's worth noticing that the BAT-associated emission levels are binding, meaning that the industries must comply with them, whereas the other types of BAT conclusions leave a room for interpretation for the competent authority.

The current reference document on BATs in the slaughterhouses and animal by-products industries is from 2005. Slaughterhouses and by-products industries that are subject to it have a production capacity of $\geq 50$ tons/day and $\geq 10$ tons/day, respectively. However, due to a quick progress in techniques and technologies, the current plan is that work on a new reference document on BATs in the slaughterhouses and animal by-products industries is to start in 2017. It is worth noticing that the general concept of BAT is not only used in connection with IED but also with industries not covered by IED.

\section{Objectives}

The objective of this study is to provide information for operators, environmental consultants and competent environmental authorities on what is and could be considered BAT for slaughterhouses and animal by-products industries. Here, more specifically, the focus will be on the Nordic country installations investigated through a questionnaire on current production patterns, potentially problematic BATs and which BATs or key environmental indicators that can be used as a basis for setting future permit conditions. Based on the survey, general ideas or guidelines will be presented and can be used during the upcoming EU revision of a new BAT-Reference document for slaughterhouses and animal by-products industries. 


\section{Overview of the Nordic sector - processes and techniques}

\subsection{Overview of the Nordic sector}

In the Nordic countries the slaughterhouse and animal by product sector covered by IED consists of approximately 65 plants. The amount was derived through DMRI knowledge, online screening and consultations with national environmental representatives (contacted through the Nordic BAT-group). The exact list is kept confidential.

Table 1: Overview of estimated amount and kind of slaughterhouse and animal by-products IED installations in Denmark, Sweden, Norway, and Finland

\begin{tabular}{|c|c|c|c|c|c|c|}
\hline \multirow[t]{2}{*}{ Country/Industry } & \multirow{2}{*}{$\begin{array}{c}\text { No. of } \\
\text { installations }\end{array}$} & \multicolumn{5}{|c|}{ Processing } \\
\hline & & $\begin{array}{l}\text { Pig \& } \\
\text { sows }\end{array}$ & $\begin{array}{c}\text { Cattle \& } \\
\text { calf's }\end{array}$ & $\begin{array}{c}\text { Sheep \& } \\
\text { lamb }\end{array}$ & Poultry & By-products \\
\hline
\end{tabular}

Denmark

$x$

$X$

Slaughterhouse

Slaughterhouse

Slaughterhouse

Animal by-products

Sweden

Slaughterhouse

Slaughterhouse

Slaughterhouse

Slaughterhouse

Slaughterhouse

Animal by-products

10

5

Norway

Slaughterhouse

Slaughterhouse

Slaughterhouse

Slaughterhouse

Slaughterhouse

Slaughterhouse

Animal by-products

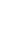

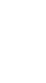

$x$

$x \quad x$

$x \quad x$

X

X

X

$x$

$x$

$x \quad x$
$\mathrm{X}$

$x$
列

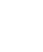

(1)




\begin{tabular}{|c|c|c|c|c|c|c|}
\hline \multirow[t]{2}{*}{ Country/Industry } & \multirow{2}{*}{$\begin{array}{c}\text { No. of } \\
\text { installations }\end{array}$} & \multicolumn{5}{|c|}{ Processing } \\
\hline & & $\begin{array}{l}\text { Pig \& } \\
\text { sows }\end{array}$ & $\begin{array}{c}\text { Cattle \& } \\
\text { calf's }\end{array}$ & $\begin{array}{c}\text { Sheep \& } \\
\text { lamb }\end{array}$ & Poultry & By-products \\
\hline \multicolumn{7}{|l|}{ Finland } \\
\hline Slaughterhouse & 2 & $x$ & & & & \\
\hline Slaughterhouse & 2 & & $x$ & & & \\
\hline Slaughterhouse & 2 & $x$ & $x$ & & & \\
\hline Slaughterhouse & 1 & $x$ & & & $x$ & \\
\hline Slaughterhouse & 3 & & & & $x$ & \\
\hline Animal by-products & 1 & & & & & $x$ \\
\hline Total & 65 & & & & & \\
\hline
\end{tabular}

\subsection{Pig slaughter}

On a mass basis, pigs represent the main slaughtering activity in the Nordic countries. The applied slaughterhouse processes and techniques often depend on the size of the installations. In general, and in the larger installations, trucks deliver pigs to the lairage of the slaughterhouse where they are kept for up to 2 hours, and from where excrements and urine are sent to anaerobic co-digestion (biogas \& sludge production) (Danish Meat Research Institute 1995). However, sometimes pigs spend the night in the lairage areas, as it is then possible to have an early processing start at the following day. From the lairage area, the pigs are driven to chambers where they are stunned with $\mathrm{CO}_{2}$ (some smaller operations may apply electricity to stun) (Finnish Environment Institute 2002). Afterwards, they are hung by their hind legs on an overhead rail and while being moved, they are stuck in the throat. From there, approx. $4 \mathrm{~kg}$ blood per pig is collected and used in fur animal feed or human consumption products. Subsequently, and after being removed from the rail, the pig hair is loosened by scalding in approx. $60{ }^{\circ} \mathrm{C}$ hot water (scalding tank) or by steam (vertical scalding) (Danish Meat Research Institute 1995; Finnish Environment Institute 2002). After the hair has been loosened, approx. $1 \mathrm{~kg}$ hair per pig can be removed (goes to rendering) in a de-hairing machine that applies rotating rubbers and pressurized water jets (Finnish Environment Institute 2002). After being hung by their hind legs on an overhead rail, the residual hair and bacteria are removed in the singeing process (e.g. propane gas burning). The singeing process leaves sooth and creates discolouration of the skin. To get a light uniform colour, the skin is scraped.

In the cleaner part of the slaughterhouse, the pigs on rails are opened, and the stomach and bowel set are taken out and cleaned in the casing department. Hereafter, the pluck sets (i.e. heart, liver and lungs) are taken out and further processed in the "pluck area" of the slaughterhouse. The pig carcass then weighs 
around $85 \mathrm{~kg}$. Heart, liver, kidneys and washed intestines are commonly sold for human consumption and pet food (Finnish Environment Institute 2002; Danish Meat Research Institute 1995). Trimmings, lungs, and washed stomachs and intestines (contents are taken to biogas \& sludge production) are used for human consumption, fur animal feed, and pet food production (Finnish Environment Institute 2002). The carcasses are then split into two (snout attachment still occurs) and chilled from approx. 35 to $7^{\circ} \mathrm{C}$ (Danish Meat Research Institute 1995). The subsequent cutting processes produce trimmings and bones, which are sent to rendering, fur animal feed and pet food. Approx. $14^{-16} \mathrm{~kg} / \mathrm{pig}$ goes to fur animal feed production or pet food, while ca. $11 \mathrm{~kg} / \mathrm{pig}$ goes to rendering (Finnish Environment Institute 2002). The mass that goes to biogas \& sludge production is approx. 8-10 kg/pig, and includes stomach and intestine contents and wastewater treatment residues (e.g. fat, sludge etc.) (Finnish Environment Institute 2002).

\subsection{Cattle slaughter}

After arrival by trucks to the slaughterhouse and stay in the lairage area, the cattle are driven to the stunning area one at a time. Here their body and heads are fixed, and they are stunned with a penetrating captive bolt device. Depending on religious rituals and targeted meat markets, the stunning can also be done with a non-penetrating captive bolt device (so skull fracture is avoided). After stunning, the cattle is hung by the hind legs on an overhead rail, and the throat is cut so bleeding can occur. Collected blood (approx. 10$22 \mathrm{~kg} / \mathrm{head}$ ) is used for fur animal feed and human consumption (Finnish Environment Institute 2002; Danish Meat Research Institute 1995). Afterwards, hides are striped from the body, and they are washed and salted before being sent to tanneries and further processing into leather goods (Finnish Environment Institute 2002). In the subsequent procedures, the head, forelegs, tail, udder or testicles are removed.

In the clean part of the slaughterhouse, the chest is cut open and stomach, intestines, and plucks are removed. Heart, liver and kidneys are used for human consumption, while udder, lungs and washed stomachs are mainly used for pet food or animal feed production - but due to latest legislation change for countries with low BSE risk the utilisation for human consumption could increase in the Nordic countries (Finnish Environment Institute 2002; Danish Agriculture \& Food Council 2015; Commission Regulation (EU) 2015/728 2015; Commission Regulation (EC) No 1069/2009 2009). The removed stomach content (approx. $60-80 \mathrm{~kg} / \mathrm{head}$ ) is sent to composting (Finnish Environment Institute 2002). If slaughtered cattle is older than 6 months than approx. 40-50 kg/head is considered specified risk material (SRM) and is incinerated, co-incinerated or 
used for fuel (meat-bone meal is incinerated, while fat is used as fuel) (Finnish Environment Institute 2002). In the end, the cow carcass weight is approx. 250$260 \mathrm{~kg} / \mathrm{head}$, and the calf carcass weight approximately half of that.

\subsection{Sheep slaughter}

Sheep and lambs are delivered by trucks to slaughterhouses and led to the lairage area. Hereafter they are stunned with a penetrating/non-penetrating captive bolt device or by electricity. Thereafter they are hung and stuck/cut so bleeding can occur. Approximately 1-2 kg of blood/head is relieved, which corresponds to $60 \%$ of the total blood mass per animal (Danish Meat Research Institute 1995). Afterwards their hide (for leather goods), stomach, intestines (for animal feed), and plucks (mainly for human consumption) are removed. The utilisation of by-products is due to the latest legislative change become easier for low risk BSE countries - the Nordic countries (Danish Agriculture \& Food Council 2015; Commission Regulation (EU) 2015/728 2015; Commission Regulation (EC) No 1069/2009 2009). In the end, the approx. $21 \mathrm{~kg} / \mathrm{head}$ slaughtered weight is showered with water to remove blood and fat residues and sent for cooling (Danish Meat Research Institute 1995). Later they can be sold as an entire carcass, divided into half's or smaller parts.

\subsection{Poultry slaughter}

Chickens are transported to slaughterhouses in crates and cages and are then manually hung by their feet onto a conveyer. Then they are conveyed to an area where they are electrically stunned (e.g. by dipping their head in an electrified water container), and later their neck artery is cut (Danish Meat Research Institute 1995). Alternatively, e.g. in Finland, $\mathrm{CO}_{2}$-stunning is also applied - there chickens are hung after stunning. The $40 \mathrm{~g} / \mathrm{chicken}$ of blood is collected and used in animal feed (Finnish Environment Institute 2002). Then they are scalded in order to ease feather removal by being dipped for approx. $2-3$ minutes in approx. $50-52{ }^{\circ} \mathrm{C}$ hot water (if later sold as fresh) or for ca. 1 minute in approx. $60^{\circ} \mathrm{C}$ hot water (if later sold as frozen) (Danish Meat Research Institute 1995). De-feathering, or plucking is performed by rotating rubber "fingers" beating/rubbing the scalded carcass and water flushing off the approx. $180 \mathrm{~g} /$ chicken of feathers. These are further processed, e.g. into animal feed (Finnish Environment Institute 2002).

The next step in the processing is to cut off the head $(80 \mathrm{~g} / \mathrm{chicken})$ and the feet (120 g/chicken) (Finnish Environment Institute 2002). The feet can continue on the conveyer for e.g. animal feed production. The rest of the chicken is moved 
onto a separate conveyer, now held in the legs, where the bowel is pulled out and gizzard, lever and heart are removed with the aim of being used for human consumption products (Danish Meat Research Institute 1995). Then the chicken is showered with water, and the trachea and esophagus are removed, followed by an inside-out water flushing of the chicken (Danish Meat Research Institute 1995). The chicken, or more precisely broiler, then weighs approx. $1.4 \mathrm{~kg}$ and is chilled to below $4^{\circ} \mathrm{C}$. Further processing produces trimmings and bones of approx. 150-160 g/broiler (Finnish Environment Institute 2002). These byproducts are used for fur animal feed production (Danish Meat Research Institute 1995; Finnish Environment Institute 2002). 



\section{Methodology}

\subsection{Goal and scope of questionnaire}

In relation to the slaughterhouses and animal by-products industries BATReference document, and more precisely the BAT conclusions, the aim with sending out a BAT-questionnaire to slaughterhouses, animal by-products installations and environmental permit writers (or environmental inspectors) is to investigate limitations and potential ideas for setting future BATs. The answers to the questionnaires are subject to confidential treatment and presentation.

The geographical scope of the installations that received the questionnaires is the Nordic countries, specifically Denmark, Sweden, Norway and Finland. The reason for only considering these Nordic countries is that the major part of the BAT relevant production occurs within these countries. The considered installations were chosen based on consultations with national environmental protection agencies and the BAT-working group.

Each of the questionnaires addresses certain BAT specific issues, relevant for installations and environmental authorities:

- Slaughterhouse installations BAT-questionnaire (see Appendix 2):

- Production patterns.

- Accounted and potentially accounted environmental indicators.

- Stand according to potential ideas for future BATs (BAT ideas were proposed based on DMRI industry experience).

- Applicability of certain dubious BATs (ones that may be difficult to follow - based on DMRI industry experience).

- Animal by-products industries BAT-questionnaire (see Appendix 3 ):

- Production patterns.

- Accounted environmental indicators.

- Potential ideas for future BATs.

- Environmental permit writers environmental indicators questionnaire (see Appendix 4):

- Country specific environmental indicators (when issuing permits and monitoring environmental impacts for/from slaughterhouses and animal by-products installations). 


\subsection{Slaughterhouse questionnaire}

The slaughterhouse questionnaire directed towards installations in the Nordic countries aims at investigating production patterns and accountable environmental indicators that could be applied in future setting of new BATs. However, the environmental indicators may also uncover limitations in the future BAT work. Also, ideas for new BATs and applicability of certain dubious BATs were raised, and installations were asked to define the level of applicability according to their line of business.

\subsubsection{Production patterns}

The installation's specific production patterns were questioned according to:

- Production capacity (BAT regulation $\geq 50$ tons/day).

- Kinds of animals slaughtered.

- Typical (hot) carcass weight of slaughtered kind of animal.

- Total yearly weight (hot carcass) of slaughtered kind of animal.

- Degree of automation at facility.

- Amount of operational weeks per year.

- Amount of production days per operational week.

- Number of work shifts per operational day.

\subsubsection{Accounted and potentially accounted environmental indicators}

The parameters that are part of the facility's ongoing operational control, and can serve as environmental indicators, are investigated in terms of how these are accounted. Furthermore, the installations are also enquired if it is possible to allocate these parameters according to slaughtering and by-products processing (cleaning of casings, fat rendering, processing of blood etc.).

The environmentally impact related parameters enquired about (both in terms of how these are accounted, and the opportunities of allocating these according to different process installations):

- Water consumption (tap water temperature).

- Heated water.

- Electricity, total.

- Electricity for cooling.

- Electricity for compressed air. 
- Fuels (oil, gas etc.).

- District heating.

- Steam.

- TOC (Total Organic Carbon) in wastewater.

- COD (Chemical Oxygen Demand) in wastewater.

- BOD (Biological Oxygen Demand) in wastewater.

- Total N (Nitrogen) in wastewater.

- Total P (Phosphor) in wastewater.

- $\quad$ FOG (Fat, Oil and Grease) in wastewater.

- $\quad$ SS (Suspended Solids) in wastewater.

- Use of cleaning detergents.

- Use of chlorine containing agents (for disinfection).

- Use of other disinfection agents.

\subsubsection{Potential ideas for future BATs}

In terms of potential ideas for future BATs, or useful considerations in future BAT work, 11 ideas were included in the questionnaire, and the installations were asked to imply if these were suitable, partially suitable or not suitable to be introduced in the future BAT proposal. Also, each installation also had the possibility to suggest own BAT related ideas.

These BAT ideas can be seen in Appendix 2, and also in the results section 3.2.4. where they are displayed along with results (level of applicability by the installations).

\subsubsection{Applicability of certain dubious BATs}

According to the current Slaughterhouses and Animal By-Products BATReference document (BREF), 28 dubious BATs were taken out, and the installations were enquired to which degree they apply these (applied; partially applied; not applied; not applicable). The selection of these BATs was based on DMRI's consultant-related industry experience - and we think that these may be difficult to follow by the installations.

The BATs chosen for the questionnaire can be seen in Appendix 1 where they are presented and assessed according to level of application, by the asked installations. 


\subsection{By-products industries questionnaire}

The by-products industries questionnaire directed towards installations in the Nordic countries aims at investigating production patterns and accountable environmental indicators that can be applied in future setting of BATs, and suitability of potential ideas for future BATs.

\subsubsection{Production patterns}

The installation specific production patterns were questioned according to:

- Production capacity (BAT regulation $\geq 10$ tons/day).

- By-products processed from which kind of animal.

- Total yearly weight of animal by-products.

- Use of received by-products.

- Amount of operational weeks per year.

- Number of work shifts per operational day.

\subsubsection{Accounted and potentially accounted environmental indicators}

For parameters that are part of the by-products installations' ongoing operational control, and can serve as environmental indicators, the installations are enquired about how these are accounted for according to the overall installation operation (total; total and divided according to departments; not accounted for). The enquired environmental indicators are shown in section 2.2.2.

\subsubsection{Potential ideas for future BATs}

The potential new ideas for future BAT work amounts to 6 suggestions, which are an excerpt from the 11 ideas suggested for slaughterhouses. The ideas were proposed on the basis of DMRI's industry experience. The enquired installations had to imply if each suggestion is suitable, partially suitable or not suitable to be introduced in the future BAT proposal - as the case was for the slaughterhouse related suggestions. Each installation also had the possibility of suggesting their own BAT related ideas.

The BAT ideas can be seen in Appendix 2, and also in the result section 3.2.4 and 3.3.2 where they are displayed along with installation scores. 


\subsection{Environmental permit writers questionnaire}

The questionnaire for the environmental permit writers, or environmental inspectors, is aimed towards highlighting which of the environmental indicators that are used in each of the considered Nordic countries when issuing permits to - and monitoring environmental impacts from - slaughterhouses and byproducts plants.

Environmental permit writers, or inspectors, were questioned according to these parameters:

- Slaughterhouses or by-products industries - use of resources?

- (e.g. drinking water, electricity, heating etc.).

- Slaughterhouses or by-products industries - emissions to air?

- (e.g. $\mathrm{CO}_{2}, \mathrm{CO}, \mathrm{NOx}$, odour, noise etc.).

- Slaughterhouses or by-products industries - emissions to water?

- (e.g. amount of wastewater, TOC, $C O D, B O D, N, P, B / 5, S S, f a t, p H$, temperature etc.).

- $\quad$ Slaughterhouses or by-products industries - emissions to soil?

- (e.g. metals, waste etc.). 



\section{Results}

\subsection{Answer percentages}

The questionnaires were sent to 52 slaughterhouses and 13 by-products industries installations that were identified as relevant for the slaughterhouse and animal byproducts industries BAT-Reference document (we think there is at least that many IED installation, as seen in section 1.1) - also 5 environmental permit writers/inspectors were enquired about which environmental indicators were considered when issuing permits or monitoring. All permit writers/inspectors answered (see Figure 1). Out of 65 slaughterhouses and animal by-products installations that were contacted, $39(60 \%)$ answered the questionnaires (see Figure 1). However, some returned questionnaires did not consider all questions. The ones that did not answer were mainly smaller installations and to some extent also related to poultry or by-products processing.

Figure 1: Percentages of questionnaires answered, along with amount of answered questionnaires according to the amount of installations contacted per questionnaire and per considered Nordic country

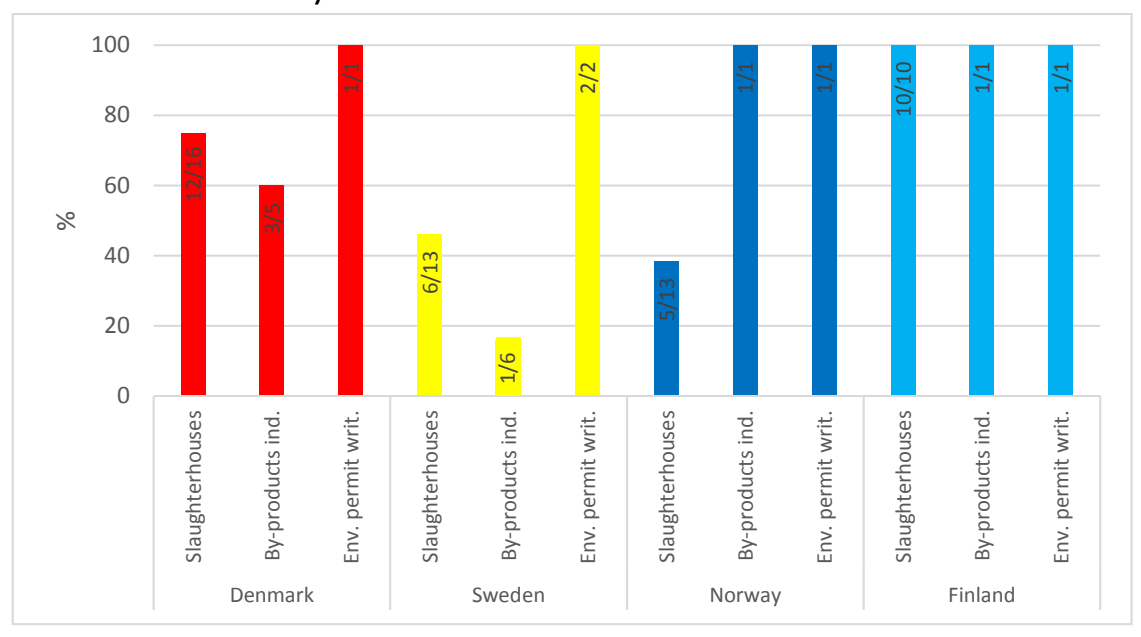




\subsection{Slaughterhouse questionnaires}

\subsubsection{Degree of automation and annual production}

There is quite a variation in the size and operation of the considered slaughterhouses (see Figure 2). In Figure 2, alongside the actual annual carcass weight per year, production ranges are denoted, and according to these, an almost uniform for 5 days a week (mainly 1 shift, some have 2 ) and for 50-52 weeks a year operational pattern was observed for all slaughterhouses. The kind of animals slaughtered and typical (hot) carcass weight can be seen in Appendix 1. All of the considered slaughterhouses have a total yearly production that is $\geq 50$ tons/day (BREF considered production capacity), but their operation pr. animal kind can be below this (as seen in Figure 2). 


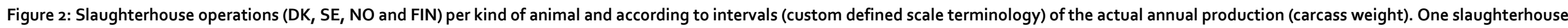
can be counted as two facility operations, e.g. by slaughtering pigs and cattle. Names of slaughterhouses are not disclosed due to confidentiality reasons

Manual Mechanical $\quad$ Mechanical \& automated (use of robot technology)

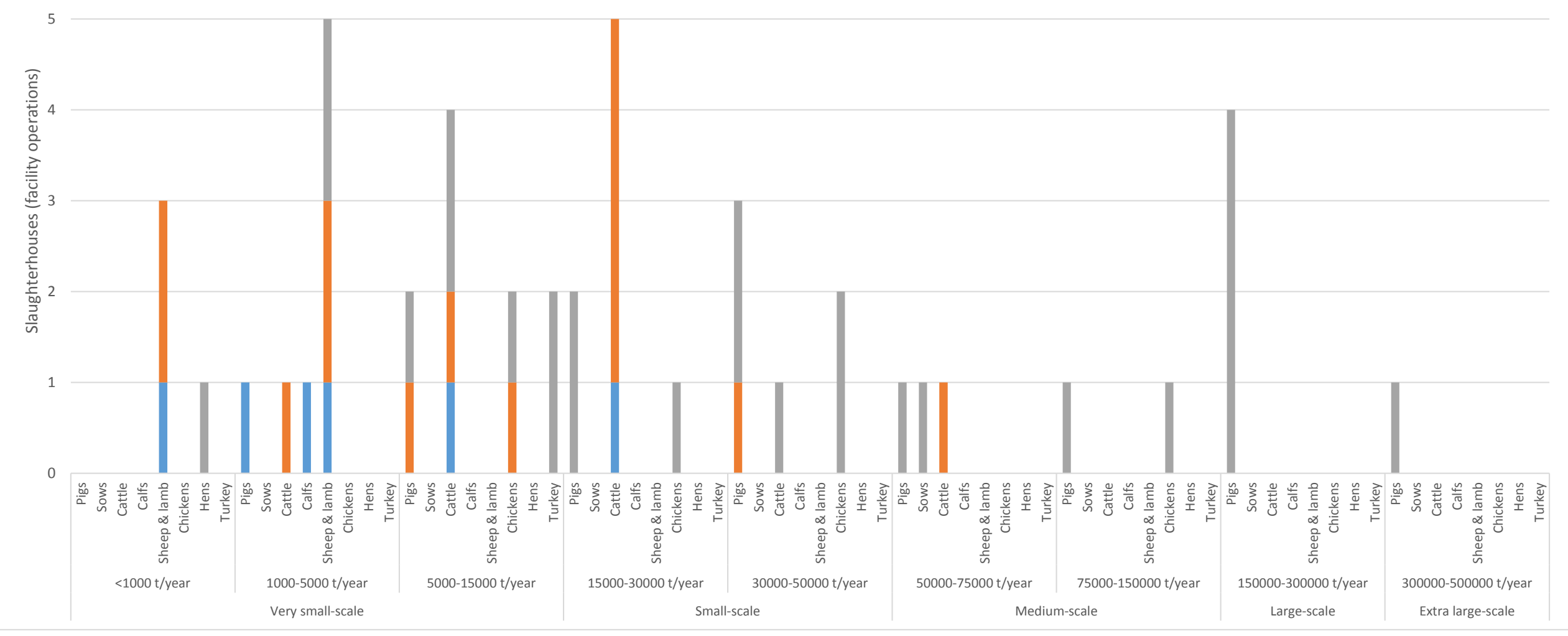


Different slaughterhouse operational patterns are seen in Figure 2, but as expected, the larger operations tend to use mechanical and automated (use of robot technology) technological approaches. Smaller operations that are subject to BREF use more mechanical and manual approaches, even though they also have introduced automated approaches. This is due to the savings in labour costs and a faster and uniform processing. Initially, from an environmental point of view, the automated approach can be worse due to a higher resource consumption (e.g. through electricity). However, the environmental impact consideration in this case also needs to consider the benefits in terms of more product produced and perhaps the minimised labour related impacts. For smaller operations, the crucial factors in potentially moving from manual to automated approaches are economical possibilities (return of investment) and the potential (seasonal) variation in production.

When considering benefits of e.g. manual vs. automated processing, the possibility of accounting environmental impacts is important, with the aim of developing environmentally friendlier slaughterhouses and related products. In this context, the coming BREF has to promote realistic and obtainable aims, according to slaughterhouse opportunities.

\subsubsection{Ongoing control and accounting of environmental parameters}

According to the existing BREF, the current key environmental issues for slaughterhouses are in general the water consumption, emission of high organic strength liquids to water (containing fats and blood), energy consumption (mainly due to water heating (e.g. for cleaning), refrigeration) (European Commission 2005). The related emission levels are defined as achievable amounts if applying BAT defined technology. These are only defined for wastewater emissions from slaughterhouses and animal by-product installations (after on-site or e.g. municipal wastewater treatment) and for incineration of animal by-products. The BAT achieved wastewater indicative emission levels are: COD (25-125 mg/l), BOD5 (10-40 mg/l), SS (5-60 mg/l), Total N (15-40 mg/l), Total P (2-5 mg/l), and FOG (2.6-15 mg/l) (European Commission 2005). The BAT achieved air emission levels for incineration of animal by-products are defined through $\mathrm{SO}_{2}, \mathrm{HCl}, \mathrm{HF}, \mathrm{NOx}, \mathrm{CO}$, VOCs, dust, dioxins and furans, heavy metals, and $\mathrm{NH}_{3}$ - see European Commission (2005) for specific levels. In relation to these, the upcoming Slaughterhouse and Animal By-Products BREF may contain new binding emission demands. For slaughterhouses, Figure 3 shows to which extent specific environmental parameters are controlled and accounted at slaughterhouses - based on slaughterhouse answers. 


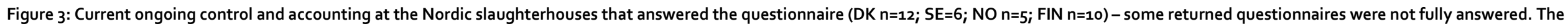
slaughterhouse scale-size intervals (processed carcass weight) are defined in Figure 2. Names of slaughterhouses are not disclosed due to confidentiality reasons

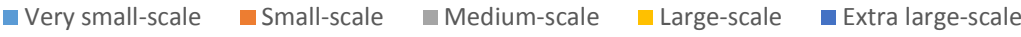

35

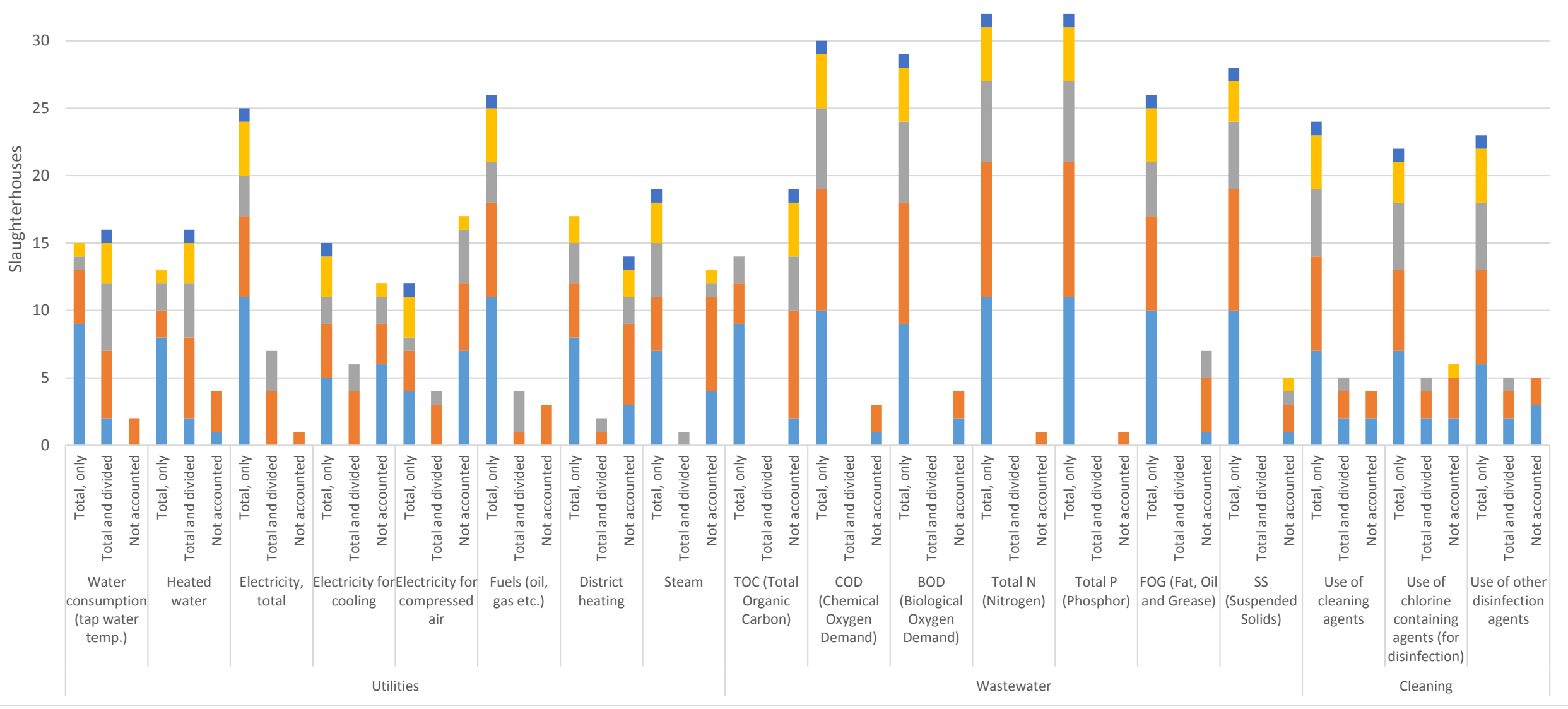


According to Figure 3, most of the environmental related parameters can be accounted for, but mainly in total numbers for whole slaughterhouses - as seen in Danish Meat Research Institute (2015). Especially, as seen for wastewater and cleaning agents indicators. In terms of utilities, the water related consumptions, and to a minor extent the electricity related consumptions, can in approx. half of the asked slaughterhouses be accounted in a more detailed fashion. In most cases, this means that some larger slaughterhouse areas are accounted separately. Indicators such as electricity for cooling, electricity for compressed air, district heating, steam, TOC are in approx. half of the installations not accounted. This can be due to that these are not considered relevant in the installations, or are accounted in an indirect fashion (e.g. through total electricity). However, e.g. compressed air is commonly not possible to be accounted in a divided fashion, as it would require measuring the amount of distributed air to each factory section.

An important aim, beside monitoring several environmental indicators, should be to consider burden shifting of environmental impacts across life cycle stages (also addressed in cross media effects BREF), e.g. lower amount of water consumption can be achieved by using a larger amount of detergents - water related impacts will be lower and detergent related impacts higher. This opens up for the use of life cycle thinking, which merely means that one should consider burden shifting (not perform actual LCAs).

\subsubsection{Possibility to allocate consumptions and environmental parameters for slaughter and by-products processing}

A relevant aspect is the ability to distribute the consumptions and environmental implications according to products produced, separately for slaughter and by-products processing (cleaning of casings, fat rendering, processing of blood etc.). The reasoning behind this is that slaughterhouse products have different value/function and that the environmental impacts need be related to them - like a functional unit in Life Cycle Assessment (LCA). The slaughterhouses were asked about the potential for allocation of selected consumptions and environmental implications - see Figure 4. 


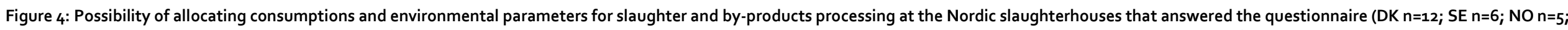

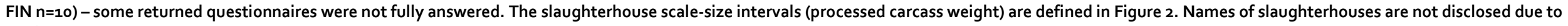
confidentiality reasons

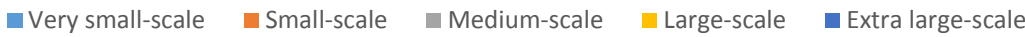

35

30
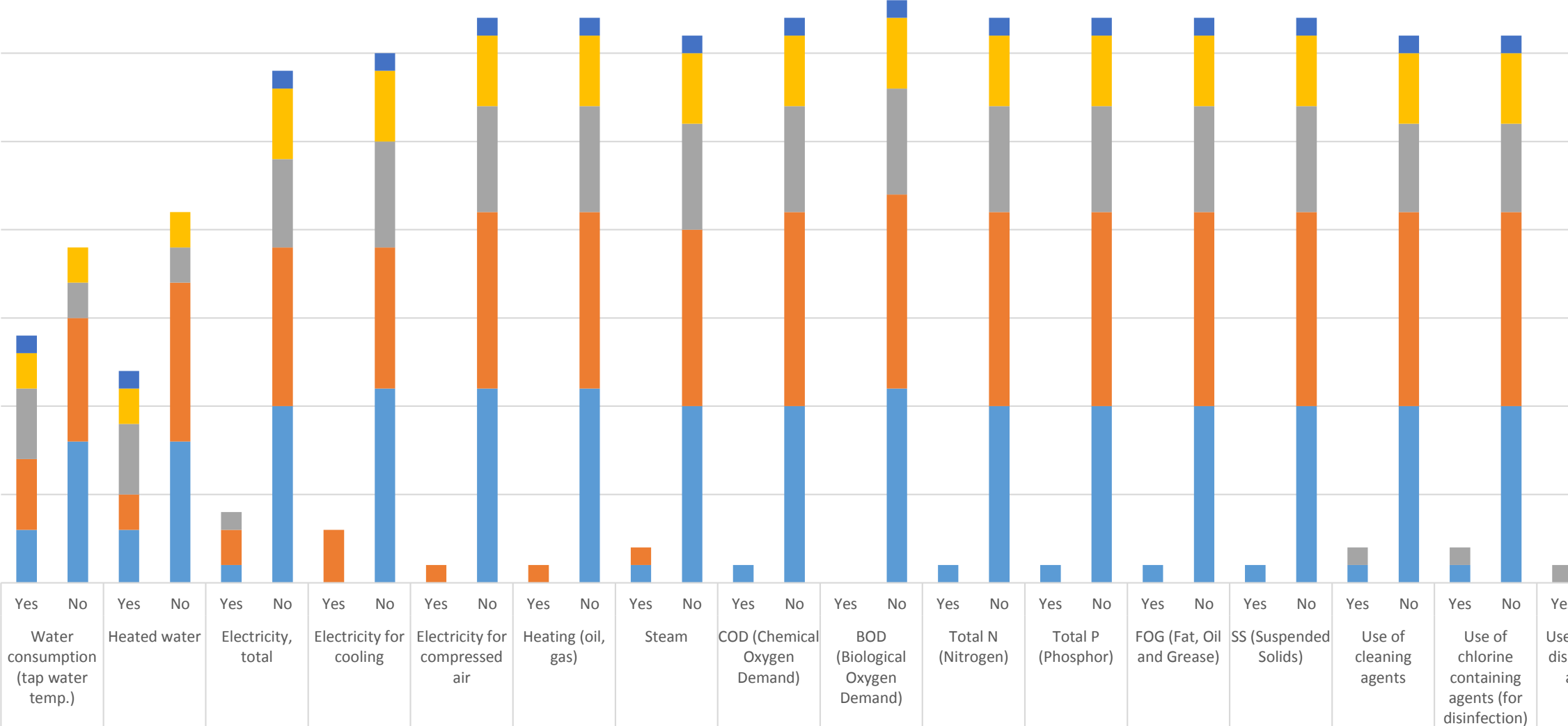

Utilities

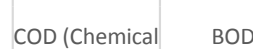

Total N

total P

Yes No Yes No

Yes No

Yes No

Oxygen

(Biological

Titrogen)

(Phosphor) FOG (Fat, O

Solids) cleaning

chlorine disife

containing
agents (for

disinfection)

aents

Cleaning 
To justify a higher energy consumption, e.g. with an improved utilisation, there is a need to allocate consumptions and environmental implications. However, according to the slaughterhouses asked, this is in most cases currently not possible in terms of slaughter and by-products processing (see Figure 4). According to them, this is only possible for water for half of the slaughterhouses asked. This needs to be changed if an improved by-products utilisation is aimed for - as today's carcass weight relation will not justify a further resource demanding processing of by-products (to e.g. human consumption). This underlines the difficulty to include binding emission demands in the future, as it could limit further processing and improved utilisation of animal by-products. Also, yield performance needs to be included in order to perform a fair comparison of e.g. a developed automated slaughterhouse and an undeveloped manual slaughterhouse.

\subsubsection{New or partially new suggested BATs - or useful considerations in the future}

Based on current slaughterhouse BATs (European Commission 2005), a list of new BATs or ideas leading to ones is proposed. These were suggested on the basis of needs we identified through DMRI expertise judgement and experience from the slaughterhouse sector, although slaughterhouses also had the opportunity to suggest ideas for new BATs. The slaughterhouses did not make suggestions. Their approach may reflect a competitive mind-set where they are cautious with suggesting or approving ideas that could lead to demands. However, the slaughterhouses shared their opinion of our BAT ideas and whether these are suitable for their installation (or the sector as a whole) - as seen in Figure 5. 


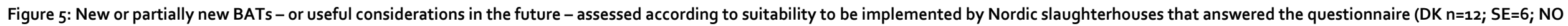

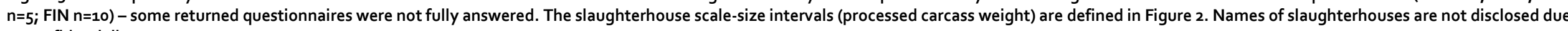
to confidentiality reasons

- Very small-scale $\quad$ - Small-scale $\quad$ Medium-scale $\quad$ - Large-scale $\quad$ Extra large-scale

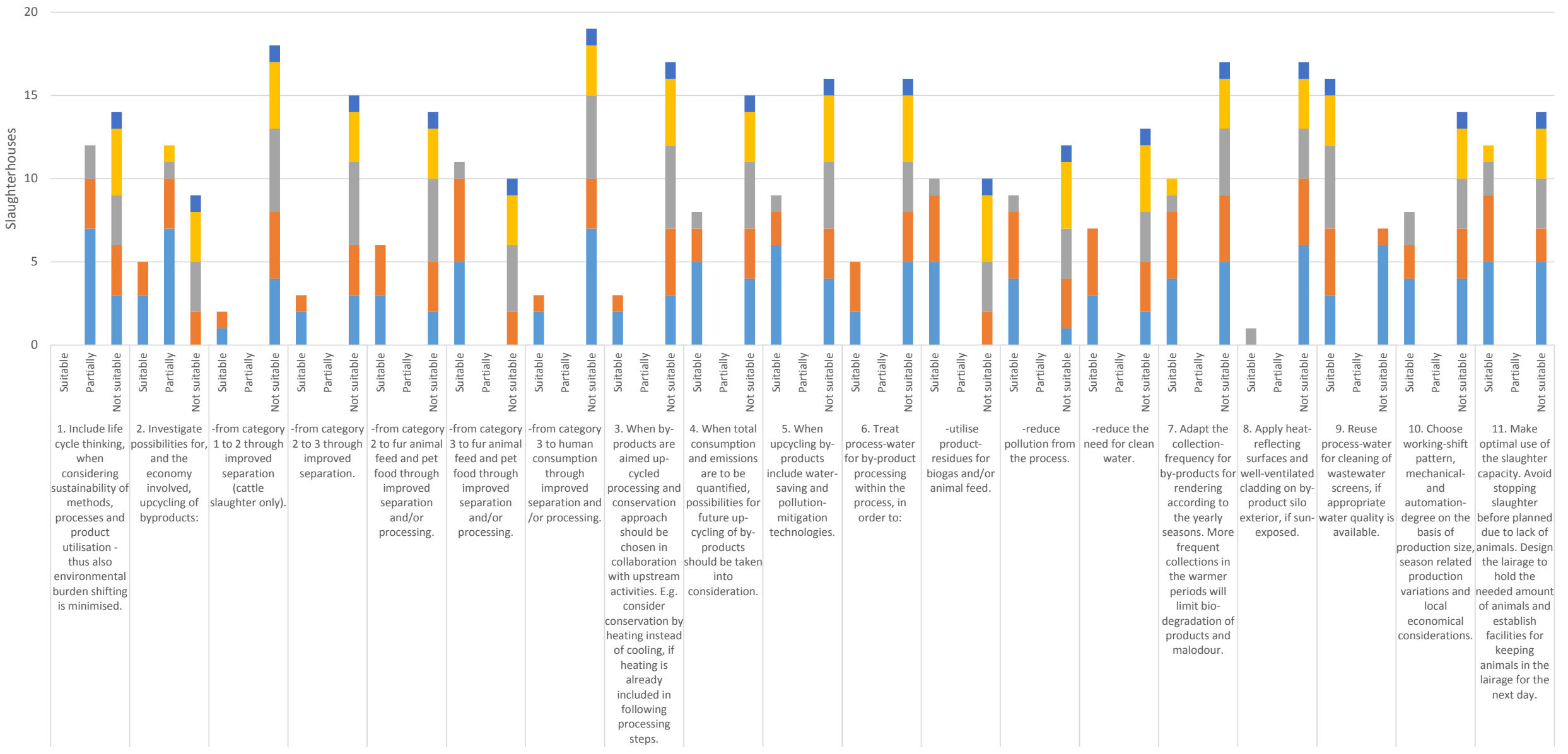


A general BAT suggestion (No. 1 in Figure 5 - low cost change) is to include life cycle thinking when considering sustainability of methods, processes and products. As previously stated, commonly there is a lack of holistic thinking when dealing with impacts, and with life cycle thinking, burden shifting of environmental impacts could be avoided. This means that a lowering of e.g. water use for cleaning by using new detergents also needs to consider the environmental impacts from detergents (burden shifting, which is also part of cross media effects BREF). Within these lines, the wider shifting of impacts needs to be thought of and not only upand down-stream in production. Half of the asked slaughterhouses find the idea partially suitable (should be implemented with modifications), and the other half does not think it should be introduced (see Figure 5).

To lower consumer related environmental impacts from an animal a suggestion is to investigate possibilities for "upcycling" (upgrade in risk category - towards human consumption) by-products (incl. economy involved) (No. 2 in Figure 5 - high cost change). This includes a larger focus on upcycling from material risk category 1 to 2 (cattle slaughter) and 2 to 3 through improved separation (See more about risk categories through European Commission (2005)). Also, it includes improved separation/processing of category 2 and 3 byproducts to fur animal feed, pet food, and even human consumption (cat. 3 ). This requires separation and processing effort and even regulatory alterations in some cases, but also financial incitement for the slaughterhouses. Slaughterhouses find the general idea suitable, but not the specific upcycling paths. Only the path from category 3 and 2 to fur animal feed and pet food is to a certain extent found suitable - mainly by the smaller installations (see Figure 5).

When aiming at upcycling by-products, the up-stream activities should be considered in order to align activities and thereby save resources and lower environmental impacts (No. 3 in Figure 5 - medium to high cost change). This can be done by e.g. considering heat- instead of cooling conservation - if heating is included in the adherent processing steps. Most slaughterhouses asked do not find this idea suitable, except for some smaller installations (see Figure 5).

When quantifying total consumptions and emissions, the slaughterhouse operation needs to consider possibilities of how this can be altered if or when future up-cycling of by-products occurs (No. 4 in Figure 5 - low cost change). Hereby the upcycled by-products increase in value and can potentially replace other animal products - this thought needs to be included when accounting total consumptions and emissions. Majority does not find this suitable, but approx. 1/3 of the slaughterhouses do (mainly smaller installations) (see Figure 5).

Include water saving and pollution-mitigation technologies when upcycling by-products - and consider emerging technologies (No. 5 in Figure 5 - high cost change). Also, if possible, treat process water from by-product processing within the same process (No. 6 in Figure 5 - high cost change). With this approach, the 
product residues can be used for biogas and/or animal feed, and the overall process pollution and input of tap water (clean water) can be reduced. This requires the introduction of emerging technologies and the acceptance of these from needed authorities (also in relation to hygiene demands of foreign markets). Little more than half of the slaughterhouses find No. 5 and 6 suitable.

The collection frequencies of by-products from slaughterhouses need to be adapted according to yearly seasons, e.g. frequent collections in warmer periods will limit bio-degradation and malodour (No. 7 in Figure 5 - low to medium cost change). Furthermore, in order to avoid e.g. bio-degradation, heat reflecting surfaces and well-ventilated cladding at by product silo exterior can be applied (No. 8 in Figure 5 - low to medium cost change). Little more than half of the asked slaughterhouses find No. 7 not suitable, the rest thinks it is suitable. In general, No. 8 is not found suitable.

In order to minimise water consumption, the process water for cleaning wastewater screens can be reused, if a suitable water quality is present (No. 9 in Figure 5 - low to medium cost change). As discussed previously, the working shift pattern and mechanical and automation degree needs to be chosen based on production size, season related production, and local economical considerations (No. 10 in Figure 5 - low cost change) - In order to support smaller businesses and their environmental efforts. About $2 / 3$ of the asked slaughterhouses find No. 9 suitable and the rest find it not suitable. In contrast, little less than $2 / 3$ find No. 10 not suitable.

Slaughtering capacity needs to be optimal, so slaughter is not stopped before planned due a lack of animals (No. 11 in Figure 5 - low to medium cost change). This will contribute to having lower environmental impacts per. processed animal. Among others this requires that the lairage area holds the needed amount of animals, also for the next day in order to achieve an early start. Half of the asked find it suitable, while others do not.

\subsubsection{Applicability of current BATs - the challenging ones}

The extent to which slaughterhouses are applying the current BATs is interesting, but mainly in terms of the more challenging BATs (dubious ones). In the questionnaire DMRI included the ones weighted as a potential challenge for the installations and related them to the actual size of facilities (carcass weight of slaughtered animals).The results are shown in Appendix 1, showing slaughterhouse level of applicability according to the BATs.

The questionnaire results (see Appendix 1) show that the slaughterhouses follow the BATs to the extent that they are relevant for each installation. Also, facilities can have solutions that are not exactly as proposed, but reach appropriate environmental aims. Certain slaughterhouses also express that they 
are not applying some BATs. An example is the "stop feeding pigs 12 hours prior to slaughter and minimise their slaughterhouse-lairage time" and "vertical steam scalding". The prior to slaughterhouses arrival feeding time is difficult to control, as farmers feed their entire stock and afterwards based on appropriate slaughter weight judgement choose the ones that should be sent for slaughter. Also, smaller facilities may not have the means to update their facilities to e.g. vertical scalding. This indicates that some smaller operations are not suited for the BATs.

\subsection{By-products installation questionnaires}

\subsubsection{Ongoing control and accounting of environmental parameters}

According to the existing BREF (European Commission 2005), the key environmental issues for by-products installations are in general the emission of high organic strength liquids to water, energy consumption (mainly due to drying by-products), treatment (incl. destruction) of TSE (Transmissible Spongiform Encephalopathies) infected material and control of odour. In relation to these, the animal by-products installations described their ongoing control and accounting of certain environmental parameters in Figure 6. 


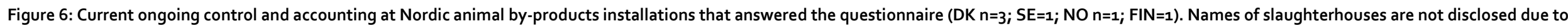
confidentiality reasons
- Facility \#1 (22,000 t/y)
In Facility \#2 (43,000 t/y)
Facility \#3 $(57,000 \mathrm{t} / \mathrm{y})$
Facility \#4 (83,488 t/y)
- Facility \#5 (145,000 t/y)
Facility \#6 (250,000 t/y)

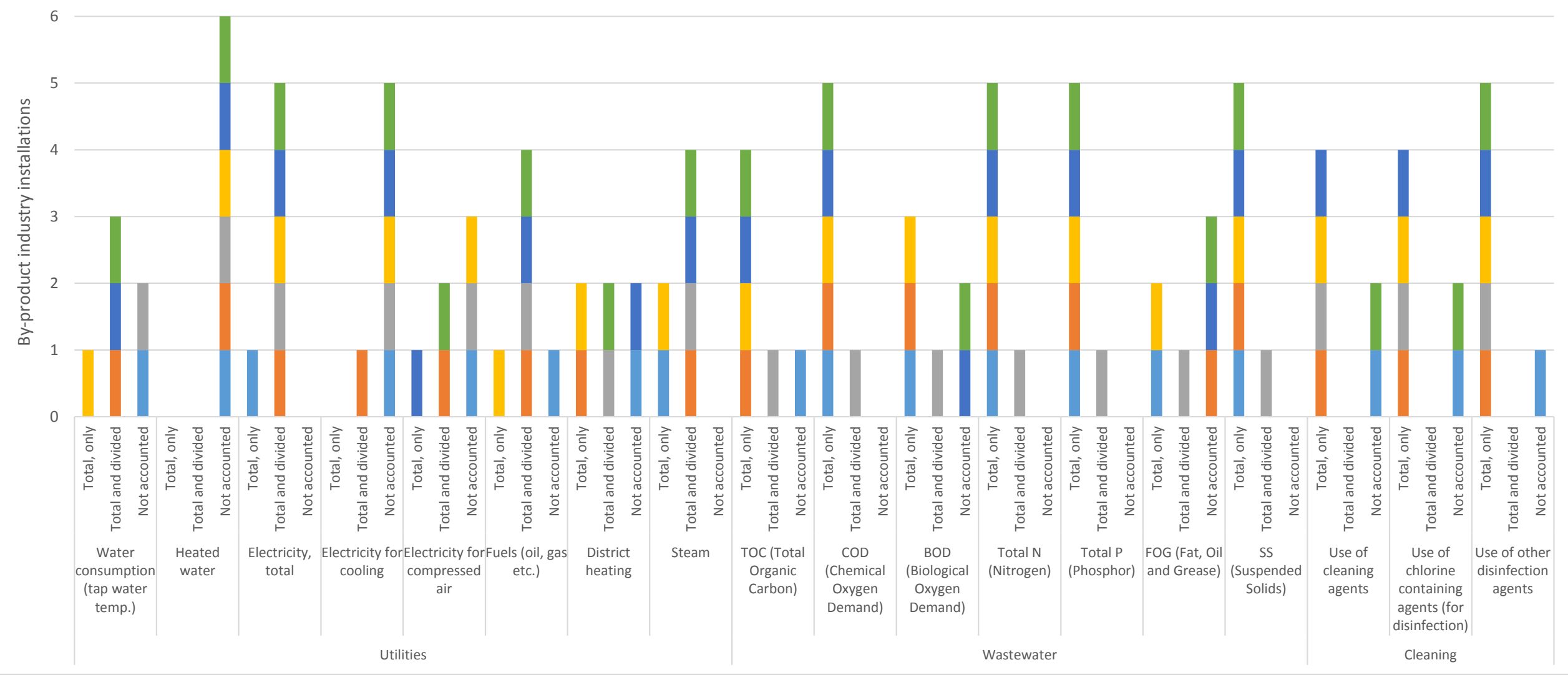


In Figure 6 it can be seen that wastewater and cleaning parameters are mainly accounted in total. This is common as wastewater usually is measured as an output from and to wastewater treatment, and the use of cleaning detergents is accounted for as mass input to the installation. Water and electricity use flows are measured for certain parts of the installation, but also in total. The need to use and account heated water and electricity for cooling/compressed air depends on installation operations. However, the need to allocate different environmental indicators may to a lesser extent be needed as by-products installations tend to have a smaller product assortment. If looking at the sizes of the facilities, there is no evidential pattern of sizes and procedures - however, the amount of installations that answered is also limited.

\subsubsection{New or partially new suggested BATs - or useful considerations in the future}

The Slaughterhouse and Animal by-products Industries BREF (European Commission 2005) needs updating, and in order to do so we suggested new BATs (or ideas for further work) - as seen in Figure 7. These, among others, were also proposed for slaughterhouses and are based on DMRI expertise judgement and experience from the slaughterhouse and animal by-product sector. As for slaughterhouses, the by-products installations had the opportunity to propose new BATs, but due to their presumably cautious approach they did not. Suitability of the own proposed BATs was assessed by the few animal byproducts installations (see Figure 7). 
Figure 7: New or partially new animal by-products industries BATs - or useful considerations - assessed according to suitability of implementation by Nordic animal by-products installations that answered the questionnaire ( $D K n=3 ; S E=1 ; N O n=1 ; F I N=1$ ). Names of by-products installations are not disclosed due to confidentiality reasons (processed by-products mass is)
Facility \#1 (22,000 t/y)
- Facility \#2 (43,000 t/y)
m Facility \#3 (57,000 t/y)
In Facility \#4 (83,488 t/y)
- Facility \#5 (145,000 t/y)
- Facility \#6 $(250,000 \mathrm{t} / \mathrm{y})$
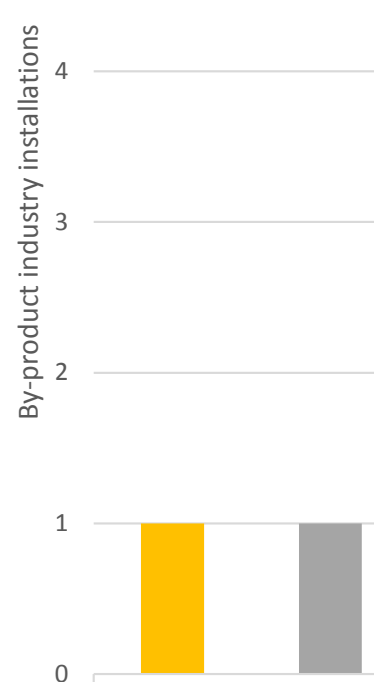

Partially

Not suitable

1. Include life cycle thinking, when considerin sustainability of methods, processes and product utitsation thus also envirenne burden shifting is minimised.

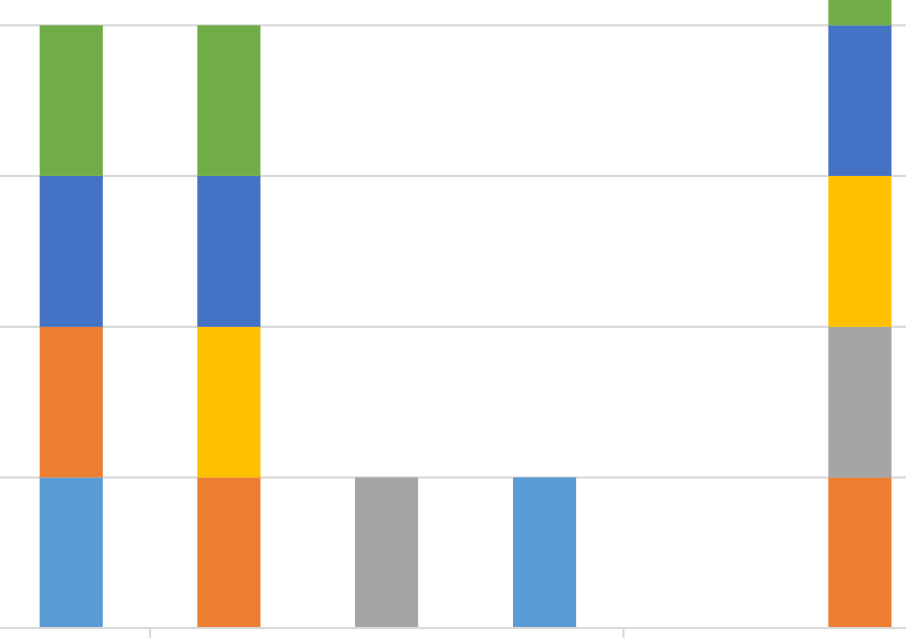

Suitable

Partially

Not suitable

Suitable

Partially products according to the yearly seasons. More ventilated coatings on by-product silo exterior.

frequent collections in the warmer periods wil

limit bio-degradation of products and malodour.

Also, avoid that material is left for next day

$$
\text { emptying. }
$$
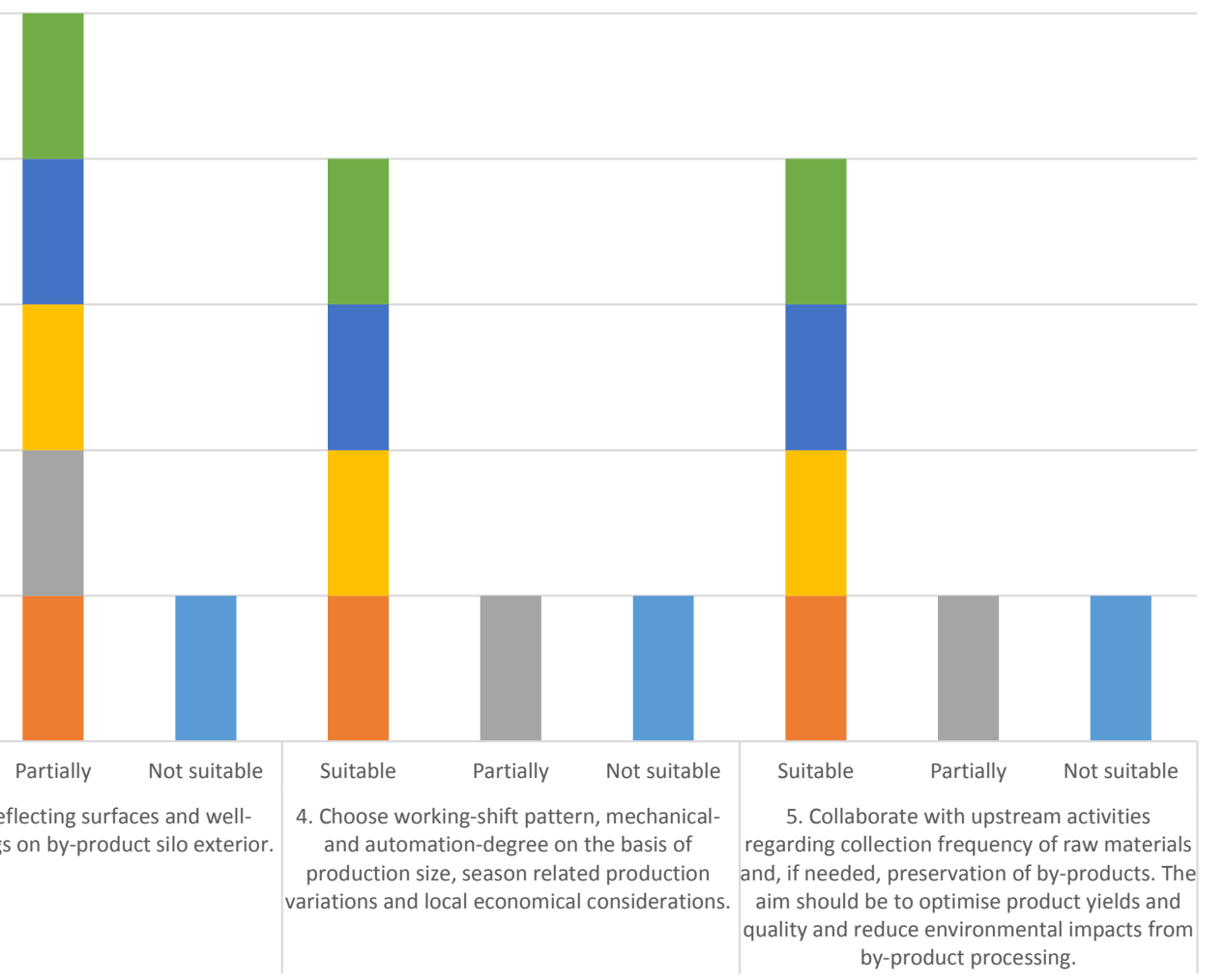
As for slaughterhouses, the proposed idea to include life cycle thinking so a more environmentally holistic approach is taken when assessing methods, processes and product utilisation was not considered suitable by the installations (No. 1 in Figure 7-low cost change). However, in the more developed countries this could be beneficial as a more fair environmental assessment would be made - as it will consider benefits and not only the down side that automated processes require more electricity compared to manual labour. Benefits can be that e.g. a higher process yield is achieved.

The adaption of collection frequency for by-products, e.g. depending on yearly seasons, is highly relevant for the installation in order to avoid neighbour complaints (smell) and also to limit product quality decay (No. 2 in Figure 7 - low to medium cost change). This idea is based on that collection frequency should be higher in summerand lower in the winter-half of the year. This idea is considered suitable by the installations.

Further, the BAT idea to apply heat reflecting surfaces and well-ventilated coatings on by-products silo exterior (to limit bio-degradation and smell) depends on the facility and their needs and local economical capabilities (No. 3 in Figure 7- low to medium cost change). One of the two alterations to the silo may only be feasible for the installations, so this could be the reason that installations mainly find this idea partially suitable.

The choice of working shift patterns and degree of automation (mechanical and automated) should be based on production, season variation and local economic considerations (No. 4 in Figure 7 - low cost change). This will set a better operational basis for smaller businesses and their environmental efforts. This idea is considered suitable as it especially refers to the smaller facilities and their operational possibilities (e.g. small fur animal feed installations in Sweden).

The idea is inspired by the already initiated up- and down-stream considerations in current BREF. However, it tries to focus on specific aspects as improved collection frequency, preservation, utilisation and quality and consideration of environmental impacts through upstream-collaboration with slaughterhouses (No. 5 in Figure 7-low cost change). It is leaning towards life cycle thinking, but is more restricted in its approach and probably thereby considered suitable by most of the installations.

\subsection{Environmental permit writer questionnaires}

In relation to the slaughterhouse and by-product installation accounted consumptions and environmental indicators, the considered national Nordic countries authorities focus on a range of environmental indicators (difference between countries occurs). This is done in order to issue necessary operational permits and due to monitoring 
purposes. The key selected environmental indicators presented in Table 2 need to be treated with caution as these are based on few environmental permit writers/inspectors answers - the full answers from each of the 5 environmental permit writers/inspectors can be seen in Appendix 5 .

Table 2: Overview of key indicators that according to questioned environmental permit writers or environmental inspectors are used in selected Nordic countries when issuing permits to and monitoring environmental impacts from slaughterhouses and by-products installations. Full answers and all stated environmental indicators can be seen in Appendix 5

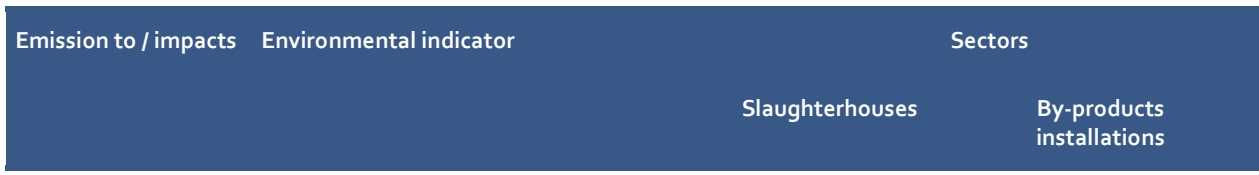

Water

$\begin{array}{lll}\text { Temp. } & \mathrm{X} & \mathrm{X} \\ \mathrm{pH} & \mathrm{X} & \mathrm{X} \\ \text { Total P } & \mathrm{X} & \mathrm{X} \\ \text { Total N } & \mathrm{X} & \mathrm{X} \\ \text { BOD } & \mathrm{X} & \mathrm{X} \\ \text { COD } & \mathrm{X} & \mathrm{X} \\ \text { SS } & \mathrm{X} & \mathrm{X} \\ \text { Fat } & \mathrm{X} & \mathrm{X}\end{array}$

Air

$\begin{array}{lll}\mathrm{CO} & \mathrm{x} & \mathrm{x} \\ \mathrm{NO} \times & \mathrm{x} & \mathrm{x} \\ \mathrm{SO} 2 & \mathrm{x} & \mathrm{x} \\ \text { Sum of } \mathrm{Ni}, \mathrm{V}, \mathrm{Cr}, \mathrm{Cu}, \mathrm{Pb} & \mathrm{x} & \mathrm{x} \\ \text { Dust }(<10 \mu \mathrm{m}) & \mathrm{x} & \mathrm{X}\end{array}$

Soil

Spill of chemicals \& products (e.g. oil, salt) $\quad$ X $\quad$ X

Nuisances

Noise

Odour

$x \quad x$

$x \quad x$

Resources use

Drinking water $\quad \mathrm{X} \quad \mathrm{X}$

Electricity $\quad x \quad x$

Heating $\quad x \quad x$

Chemicals $\quad x \quad x$

Waste management 
As seen in Table 2, there is mainly a focus on wastewater quality, combustion gases, energy and water use, and noise and odour. This goes in line with what slaughterhouses and by-product installations currently account (see Figures 3 \& 6). However, these refer mainly to the measurement of total consumptions or emissions, which does not give a picture of how the actual contributions vary from inside the slaughterhouse and byproduct installation. The actual slaughterhouse processes responsible for the environmental impacts (emissions to) are further explained in Table 3 (Section 3.5), along with suggested mitigation measures. To allocate environmental impacts according to processes is very difficult (as indicated in Figure 4), and requires substantial investments and increased effort from both the slaughterhouses and by-products installations and the authorities.

\subsection{Slaughterhouse processes, impacts and measures}

Slaughterhouse processes, environmental impacts and authority driven environmental indicators are related. The relation, based on the questioned Nordic slaughterhouses, is explained in Table 3. Further, technique based measures can be introduced and the relative environmental footprint can be reduced - also described in Table 3.

Table 3: Overview of slaughterhouse processes/techniques, their environmental impacts/emission to compartments, and related measures to minimise environmental impacts. Content is based on DMRI industry experience and expertise

\begin{tabular}{|c|c|c|c|c|c|c|c|}
\hline \multirow{3}{*}{$\begin{array}{l}\text { Process/ } \\
\text { department }\end{array}$} & \multicolumn{6}{|c|}{ Environmental impacts } & Measures to reduce environmental impacts \\
\hline & \multicolumn{2}{|c|}{ Consumption } & \multicolumn{4}{|c|}{ Direct emission/pollution } & \\
\hline & Water & Energy & ww & Air & Odour & Noise & \\
\hline
\end{tabular}

\begin{tabular}{|c|c|c|c|c|c|c|c|}
\hline Reception & $x$ & - & $x$ & - & $x$ & - & $\begin{array}{l}\text { Dry scrape before washing vehicles }{ }^{1-3} \text {. } \\
\text { Use high pressure low volume washing equipment }{ }^{1-4} \\
\text { Negative pressure in the building } g^{1-4} \text {. } \\
\text { Extract air from ventilation system through } \\
\text { chimney/stack }{ }^{1-4}\end{array}$ \\
\hline Lairage & - & - & $x$ & - & $x$ & - & $\begin{array}{l}\text { Improved dry collection of manure }{ }^{1-3} \text {. } \\
\text { Shorter lairage holding times } \mathrm{s}^{1-3} \\
\text { Extract air through a taller chimney/s++tack }{ }^{1-4} \text {. } \\
\text { Treat emitted air, e.g. with filters }{ }^{1-3}\end{array}$ \\
\hline $\begin{array}{l}\text { Stunning and de- } \\
\text { bleeding }\end{array}$ & - & - & $x$ & - & $x$ & - & $\begin{array}{l}\text { Improve blood collection }{ }^{1-3} \text {. } \\
\text { Extract air through a taller chimney/stack }{ }^{1-4} \\
\text { Treat emitted air, e.g. with filters'-4 }\end{array}$ \\
\hline
\end{tabular}




\begin{tabular}{|c|c|c|c|c|c|c|c|}
\hline \multirow{3}{*}{$\begin{array}{l}\text { Process/ } \\
\text { department }\end{array}$} & \multicolumn{6}{|c|}{ Environmental impacts } & \multirow{3}{*}{$\begin{array}{l}\text { Measures to reduce environmental impacts } \\
\text { Pigs }^{1} \text {, Cattle }{ }^{2} \text {, Sheep }{ }^{3} \text {, Poultry }\end{array}$} \\
\hline & \multicolumn{2}{|c|}{ Consumption } & \multicolumn{4}{|c|}{ Direct emission/pollution } & \\
\hline & Water & Energy & WW & Air & Odour & Noise & \\
\hline Unclean slaughter & $x$ & $x$ & $x$ & $x$ & $x$ & - & $\begin{array}{l}\text { Collect products and by-products before they end up } \\
\text { in WW stream }{ }^{1-3} \text {. } \\
\text { Perform water and energy efficiency cleaning }{ }^{1-4} \\
\text { Recycle water from cleaner to more dirty processes }{ }^{1-4} \\
\text { Apply more energy and water efficient technologies } \\
\text { (e.g. steam scalding, singeing (exhaust) energy } \\
\text { recovery) })^{1-4} \\
\text { Extract air through a taller chimney/stack }{ }^{1-4} \text {. } \\
\text { Treat emitted air, e.g. with filters }{ }^{1-3}\end{array}$ \\
\hline Clean slaughter & $x$ & $x$ & $x$ & - & - & - & $\begin{array}{l}\text { Collect products and by-products before they end up } \\
\text { in WW stream }{ }^{1-3} \text {. } \\
\text { Recycle water from cleaner to more dirty processes }{ }^{1-4} \\
\text { Apply more energy and water efficient slaughter } \\
\text { technologies (e.g. spray knife sterilisers) }\end{array}$ \\
\hline Chilling & - & $x$ & - & - & - & - & Apply a more energy efficient chilling technology ${ }^{1-4}$ \\
\hline Cutting & - & - & - & - & - & - & - \\
\hline Dispatch & - & - & - & - & - & - & - \\
\hline Cleaning of casing & $x$ & - & $x$ & - & $x$ & - & $\begin{array}{l}\text { Recycle water from cleaner to more dirty processes }{ }^{1-3} \text {. } \\
\text { Collect residues before they end up in WW stream }{ }^{1-3} \\
\text { Utilise paunch manure as a medium for composting or } \\
\text { vermiculture }{ }^{2} \text {. } \\
\text { Extract air through a taller chimney/stack }{ }^{1-3} \\
\text { Treat emitted air, e.g. with filters }{ }^{1-3}\end{array}$ \\
\hline $\begin{array}{l}\text { Pluck, cutting and } \\
\text { chilling }\end{array}$ & - & $x$ & - & - & - & - & Apply a more energy efficient technology ${ }^{1-4}$ \\
\hline $\begin{array}{l}\text { Hygienic blood } \\
\text { collection }\end{array}$ & $x$ & $x$ & $x$ & - & - & - & $\begin{array}{l}\text { Apply a more energy efficient blood collection } \\
\text { technology } \\
\text { Collect blood spillage (e.g. via trays) }{ }^{1-3}\end{array}$ \\
\hline Fat rendering & - & $x$ & $x$ & - & $x$ & - & $\begin{array}{l}\text { Collect residues before they end up in WW stream }{ }^{1-3} \text {. } \\
\text { Extract air through a taller chimney/stack }{ }^{1-3} \\
\text { Treat emitted air, e.g. with filters }{ }^{1-3}\end{array}$ \\
\hline $\begin{array}{l}\text { By-products for } \\
\text { rendering }\end{array}$ & - & - & $x$ & - & $x$ & - & $\begin{array}{l}\text { Collect by-products before they end up in WW } \\
\text { stream }^{1-3} \text {. } \\
\text { Extract air through a taller chimney/stack } \mathrm{s}^{1-3} \\
\text { Treat emitted air, e.g. with filters }{ }^{1-3}\end{array}$ \\
\hline
\end{tabular}




\begin{tabular}{|c|c|c|c|c|c|c|c|}
\hline \multirow{3}{*}{$\begin{array}{l}\text { Process/ } \\
\text { department }\end{array}$} & \multicolumn{6}{|c|}{ Environmental impacts } & \multirow{3}{*}{$\begin{array}{l}\text { Measures to reduce environmental impacts } \\
\text { Pigs }^{1}, \text { Cattle }^{2} \text {, Sheep }{ }^{3}, \text { Poultry }\end{array}$} \\
\hline & \multicolumn{2}{|c|}{ Consumption } & \multicolumn{4}{|c|}{ Direct emission/pollution } & \\
\hline & Water & Energy & wW & Air & Odour & Noise & \\
\hline $\begin{array}{l}\text { Refrigeration } \\
\text { system }\end{array}$ & $x$ & $x$ & - & - & - & $x$ & $\begin{array}{l}\text { Apply a more energy and water efficient refrigeration } \\
\text { technology } y^{1-4} \\
\text { Apply noise insulation }^{1-4} \text {. } \\
\text { Use water efficient cleaning procedures }{ }^{1-4}\end{array}$ \\
\hline $\begin{array}{l}\text { Production of heat } \\
\text { and hot water and } \\
\text { technical } \\
\text { installations }\end{array}$ & - & $x$ & $x$ & $x$ & - & $x$ & $\begin{array}{l}\text { Improve surveillance of water flows }{ }^{1-4} \\
\text { Introduce more energy efficient heating and heated } \\
\text { water production }{ }^{1-4}\end{array}$ \\
\hline $\begin{array}{l}\text { Wastewater } \\
\text { treatment }\end{array}$ & $x$ & - & - & - & $x$ & - & $\begin{array}{l}\text { Use screens and/or sedimentation traps to minimise } \\
\text { products and by-products in } W^{1-4} \\
\text { Use equalisation/balancing tank with hydraulic } \\
\text { retention time of } 6-12 \text { hours to reduce use of reagents } \\
\text { and overall size of plant }{ }^{1-4} \\
\text { If legally possible, further cleaning of wastewater and } \\
\text { reuse in own or neighbouring factory }{ }^{1-4}\end{array}$ \\
\hline $\begin{array}{l}\text { Transport to and } \\
\text { from facility }\end{array}$ & - & - & - & - & $x$ & $x$ & $\begin{array}{l}\text { Optimise routes (e.g. minimise passing and waiting } \\
\text { close to neighbours) } \\
\text { Raise noise dampening walls }{ }^{1-4}\end{array}$ \\
\hline
\end{tabular}

The environmental impact contribution from slaughterhouse processes/techniques is based on releases to water, air and soil. These can be in various forms, ranging from different chemicals to noise and affecting throughout different compartments. The presented measures to minimise environmental impacts in Table 3 are to some extent considered BATs, but also new aspects are included and can serve as an addition to the already proposed BAT ideas in Section 3.2.4. Installations can pursue these measures and promote environmentally friendly techniques. Further, these can also help in order to abide the authority set key environmental indicators, as presented in Section 3.4. 


\section{Discussion and conclusions}

This study included smaller (manual) to larger (automated) Nordic slaughterhouses and by-product installations that are subject to BREF. The study was based on questionnaires combined with general experiences from DMRI (until 2009, Slagteriernes Forskningsinstitut) who has worked with research and consultancy in the sector for more than 60 years.

The study gives an insight to the Nordic sector, where a total of approximately 65 installations are covered by BREF. Out of these, 33 installations from Denmark, Sweden, Norway and Finland answered the questionnaires.

Regarding ongoing control and accounting of environmental parameters. The respondents of the questionnaires indicated that they currently mainly account their utility consumptions, wastewater and detergents in a total manner. However, water and to some extent electricity flows are also accounted in a more divided fashion. Slaughterhouses have stressed that division of accounted environmental indicators is not possible according to slaughter and by-products activities, except for water. Allocation of environmental impacts according to processes is very difficult and requires substantial investments and increased effort from both the slaughterhouses and by-products installations and the authorities. However, these key indicators also depend on the local environmental conditions (e.g. noise, smell, wastewater treatment). This could set the basis that certain environmental implications are easier and better regulated on a local level, instead of through BREF.

The differentiation in answers between smaller and larger slaughterhouses is not evident, but in our opinion there is a difference and it is mainly represented in the local possibilities (e.g. economy \& return of investment). The reason behind the not so evident differences in results of different sizes of installations can be explained by the difficulty to include smaller installations. Perhaps their limited availability of resources/manpower is the reason. Thus, smaller operations may not be suited for the BATs, and there can be a need to further adjust and consider the BATs according to small installations - if the aim is to promote environmentally friendlier solutions through inclusion.

In order to promote sustainable solutions up-stream and limit accounting difficulties at slaughterhouses, DMRI suggests that equipment manufacturers should consider BAT in their work, as this currently is almost non-existing. 
Considering the 11 slaughterhouse and 6 animal by-products installation proposed BATs, a cautious acceptance approach was met. This could be due to the competition that the slaughterhouses are experiencing, and do not want to impose limitations on themselves that result in higher expenses and potential restrictions. This meant that slaughterhouses mainly rejected the proposed BAT ideas, while by-products installations did mainly like the ones proposed for their sector. However, the current potentially questionable slaughterhouse BATs are followed by the installations, unless they are irrelevant to their operation.

Some of the proposed BATs point towards a more holistic environmental thinking, where fair environmental benchmarking is performed. This means that more processing and improved utilisation, of e.g. by-products from a cow (to e.g. human consumption), could justify a higher energy consumption. This could mean environmental benefits, and perhaps economic gain for the installations. However, one needs to be aware of potential burden shifting of environmental impacts, when accounting or introducing BAT demands. Potential introduction of emission demands (AELs) needs to consider the needed additional processing in order to achieve a better utilisation of animal by-products.

The key environmental indicators, regulated by the environmental permit issuing authorities, are in general focussing on wastewater quality, combustion gases, energy and water use, and noise and odour. The slaughterhouse processes contributing to these were also explained, along with suggestions to which measures slaughterhouse installations can take to lower their environmental impacts and abide the authority set key environmental indicators.

An overall conclusion is that the study gives an overview of the sector, the used BATs and proposes new BATs. Furthermore, the study indicates what the key environmental issues are from the sectors point of view and from a selected number of permit writers point of view. 


\section{References}

Danish Meat Research Institute (1995). Rentek Database - Kødbranchen. Slagteriernes Forskiningsinstitut (Danish Meat Research Institute). Denmark.

Danish Meat Research Institute (2015). Opdatering af materiale om slagteriers miljøforhold. Karen Sørensen \& Ole Pontoppidan (DMRI). Notat udarbejdet for Miljøstyrelsen. Denmark.

Daddi, T., M.R. De Giacomo, G. Rodríguez Lepe, L. Vazquez Calvo, E. Dils \& L. Goovaerts (2012). A method to implement best available techniques in South Mediterranean countries: the experience of BAT4MED project. Environ. Econ. 3 (4), 65-74.

Danish Agriculture \& Food Council (2015). Oversigt over SRM før og efter de forventede lovgivningsændringer i 2015. Kødbranchens Fællesråd. MBS 3/15.

Commission Regulation (EC) No 1069/2009 (2009) of the European Parliament and of the Council of 21 October 2009 laying down health rules as regards animal by-products and derived products not intended for human consumption and repealing Regulation (EC) No 1774/2002 (Animal by-products Regulation). European Union.

Commission Regulation (EU) 2015/728 (2015) Amending the definition of specified risk material set out in Annex V to Regulation (EC) No 999/2001 of the European Parliament and of the Council laying down rules for the prevention, control and eradication of certain transmissible spongiform encephalopathies. European Union.

European Commission (2005). Reference Document on Best Available Techniques in the Slaughterhouses and Animal By-Products Industries. European IPPC Bureau at the Institute for Prospective Technological Studies. Seville. Spain.

European Parliament and Council (2010). Directive 2010/75/EU of the European Parliament and of the Council of 24 November 2010 on industrial emissions (integrated pollution prevention and control). Official Journal of the European Union.

Finnish Environment Institute (2002). Finnish expert report on best available techniques in slaughterhouses and installations for the disposal or recycling of animal carcasses and animal waste. Report 539. Finnish Environment Institute. Helsinki, Finland.

Salminen, E., R. Valo, M. Korhonen \& R. Jernlås (2014). Wood Preservation With Chemicals - Best Available Techniques (BAT). Nordic Council of Ministers. 



\section{Summary (in Danish)}

Nordisk Ministerråd, BAT-gruppen under arbejdsgruppen for Holdbar Konsumtion og Produktion (HKP), har udvalgt Danish Meat Research Institute (DMRI) til at udføre en konsulentopgave med det formål at udarbejde en rapport om "bedst tilgængelige teknikker" (BAT, Best Available Techniques) for slagterier og virksomheder, der forarbejder animalske biprodukter i Norden. Studiet er hovedsageligt baseret på en spørgeskemaundersøgelse af BREF-underlagte slagterier og virksomheder, der forarbejder animalske biprodukter i Danmark, Sverige, Norge og Finland, og undersøger de nuværende produktionsmønstre, ressourceforbrug og emissioner $\mathrm{i}$ forhold til de omdiskuterede BATs (BATs, der kan være vanskelige at følge for installationerne baseret på egen brancheerfaring) og mening omkring udvalgte nye BAT-ideer (foreslået på basis af egen brancheerfaring). Desuden blev personer fra miljømyndighederne også spurgt om de vigtigste miljøparametre, de anvender i forbindelse med udstedelse af miljøgodkendelser og miljøtilsyn af slagterier og virksomheder, der forarbejder animalske biprodukter. Resultaterne fra undersøgelsen kan benyttes af operatører, konsulenter og miljømyndigheder til input i den kommende EU-proces, der har til formål at udarbejde en ny BREF for slagterier og virksomheder, der forarbejder animalske biprodukter.

I forbindelse med spørgeundersøgelsen blev der indsamlet 33 svar fra slagterier, 6 fra virksomheder, der forarbejder biprodukter, og 5 fra miljømyndighederne. De større slagterier benytter sig i højere grad af mekaniske og automatiserede procestilgange (robotteknologi), mens de mindre slagterier benytter sig af en blanding af manuelle, mekaniske og automatiserede tilgange. Automatiseret produktion kræver mere energi (f.eks. elektricitet), men miljøpåvirkningerne fra disse bør også inkludere fordelene ved en effektiviseret produktion.

I henhold til BREF'en stammer de generelle miljøpåvirkninger fra slagterier og virksomheder, der forarbejder biprodukter, fra vandforbrug, udledning af organiske stoffer til vand (indeholdende fedt og blod), energiforbrug (primært ifm. opvarmning af vand til rengøring, køling og tørring af biprodukter), behandling (inkl. forbrænding) af TSE-inficerede materialer og lugt. Grænseværdierne for emissioner er defineret som opnåelige værdier (hvis BATs er anvendt) for spildevandsudledning fra slagterier og virksomheder, der forarbejder biprodukter (efter spildevandsbehandling), og for forbrænding af animalske biprodukter. På nuværende tidspunkt opgør de adspurgte 
installationer deres vand-, energi- og ressourceforbrug, spildevand og detergenter primært i totale mængder. For slagterierne er det i de fleste tilfælde ikke muligt at opdele disse, f.eks. i forbindelse med slagtning og biproduktprocessering.

Slagterierne overholder de omdiskuterede BATs, hvis de ikke er irrelevante for deres operation. Igennem vores forslag til nye BATs ( 11 for slagterier \& 6 for virksomheder, der forarbejder animalske biprodukter), som er udarbejdet på baggrund af vores brancheerfaring, så er der bl.a. foreslået en mere holistisk miljøtænkning, der kan danne bedre grundlag for miljøvenligere løsninger. Dette betyder, at yderligere processering og forbedret udnyttelse af f.eks. biprodukter fra en ko (der i sin levetid har en væsentlig miljøpåvirkning) kan retfærdiggøres i henhold til miljøet. Dette kan resultere i mindskede miljøpåvirkninger og øget økonomisk interesse fra installationerne. Yderligere er det vigtigt at være opmærksom på mulige byrdeskift af miljøpåvirkninger fra en del af livscyklus til en anden, når nye BATs introduceres. Mulig forestående introduktion af bindende udledningskrav (AELs) bliver nødt til at tage hånd om den yderligere forarbejdning af biprodukter, mod en forbedret udnyttelse af animalske biprodukter.

De adspurgte personer, der fører miljøtilsyn og udsteder miljøtilladelser, havde primært fokus på miljøparametre, der omhandlede spildevandskvalitet, forbrændingsgasser, energi- og vandforbrug samt støj- og lugtgener. Dette er i overensstemmelse med, hvad slagterier og virksomheder, der forarbejder animalske biprodukter, på nuværende tidspunkt opgør i totale mængder. Årsagerne til slagteriernes proces-miljøpåvirkninger er blevet forklaret og sat i forbindelse med mulige tiltag til at mindske disse. 


\section{Appendix 1: Slaughterhouse BAT questionnaire results}

Attachment to be found here:

http://urn.kb.se/resolve?urn=urn:nbn:se:norden:org:diva-4717 



\section{Appendix 2: Slaughterhouse questionnaire}

\section{Questionnaire (for slaughterhouses)}

Project on Best Available Techniques (BAT) for Slaughterhouses and Animal By-products industries in the Nordic Countries.

${ }^{*}$ Required

\section{Person answering/contact person? *}

Name, contact information (mail, phone number) and company-affiliation.

2. Country where the slaughtering facility is located? -one facility per questionnaire. Mark only one oval.
Finland
Denmark
Norway
Sweden

3. Address of the slaughtering facility? -one facility per questionnaire.

4. Total operational capacity of the slaughtering facility? Mark only one oval.

More or equal than 50 tons/day?

Less than 50 tons/day? 
5. Animal/s processed at slaughtering facility? Check all that apply.

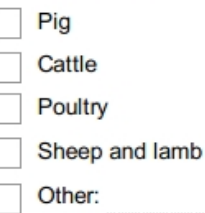

6. Total yearly weight of slaughtered animals? -specify in (hot) carcase weight per animal origin.

7. Typical (hot) carcase weight pr. slaughtered animal?

8. Degree of automation at facility Mark only one oval.

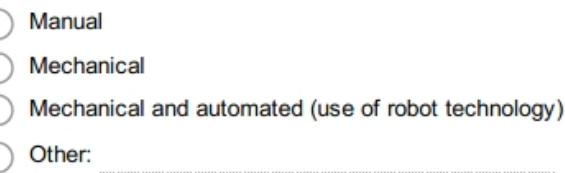

9. What is your seasonal variation in production? -amount of operational weeks/year. 
13. Which functional unit is used to evaluate facility consumption of resources over time?

(e.g. to justify increase in total resource consumption)

Check all that apply.

$\square$ Per slaughtering (per animal)

$\square$ Live weight

$\square$ Carcase weight

$\square$ Other:

14. Is it possible to allocate the consumptions and potential environmental implications separately for slaughter and by-products processing (cleaning of casings, fat rendering, processing of blood etc.)?

Mark only one oval per row.

Water consumption (tap water
temperature)
Heated water
Electricity, total
Electricity for cooling
Electricity for compressed air
Heating (oil, gas)
Steam
COD (Chemical Oxygen Demand)
in wastewater
BOD (Biological Oxygen Demand)
in wastewater
Total N (Nitrogen) in wastewater
Total P (Phosphor) in wastewater
FOG (Fat, Oil and Grease) in
wastewater
SS (Suspended Solids) in
wastewater
Use of cleaning detergents
Use of chlorine (as disinfection
agent)
Use of other disinfection agents


15. New or partially new suggested BATs - or usefull consideration in future work -relate to if these are suitable for your facility and sector in general.

Mark only one oval per row.

\begin{tabular}{|c|c|c|c|}
\hline & $\begin{array}{l}\text { Suitable (should } \\
\text { be introduced) }\end{array}$ & $\begin{array}{l}\text { Partially (should be } \\
\text { introduced with } \\
\text { modifications) }\end{array}$ & $\begin{array}{l}\text { Not suitable (not } \\
\text { to be introduced) }\end{array}$ \\
\hline $\begin{array}{l}\text { 1. Include life } \\
\text { cycle thinking, } \\
\text { when considering } \\
\text { sustainability of } \\
\text { methods, } \\
\text { processes and } \\
\text { product utilisation } \\
\text { - thus also } \\
\text { environmental } \\
\text { burden shifting is } \\
\text { minimised. }\end{array}$ & & & \\
\hline $\begin{array}{l}\text { 2. Investigate } \\
\text { possibilities for, } \\
\text { and the economy } \\
\text { involved, } \\
\text { upcycling of } \\
\text { byproducts: }\end{array}$ & & & \\
\hline $\begin{array}{l}\text {-from category } 1 \\
\text { to } 2 \text { through } \\
\text { improved } \\
\text { separation (cattle } \\
\text { slaughter only). }\end{array}$ & & & \\
\hline $\begin{array}{l}\text {-from category } 2 \\
\text { to } 3 \text { through } \\
\text { improved } \\
\text { separation. }\end{array}$ & & & \\
\hline $\begin{array}{l}\text {-from category } 2 \\
\text { to fur animal feed } \\
\text { and pet food } \\
\text { through improved } \\
\text { separation and/or } \\
\text { processing. }\end{array}$ & & & \\
\hline $\begin{array}{l}\text {-from category } 3 \\
\text { to fur animal feed } \\
\text { and pet food } \\
\text { through improved } \\
\text { separation and/or } \\
\text { processing. }\end{array}$ & & & \\
\hline $\begin{array}{l}\text {-from category } 3 \\
\text { to human } \\
\text { consumption } \\
\text { through improved } \\
\text { separation and /or } \\
\text { processing. }\end{array}$ & & & \\
\hline $\begin{array}{l}\text { 3. When by- } \\
\text { products are } \\
\text { aimed up-cycled } \\
\text { the processing } \\
\text { and conservation } \\
\text { approach should } \\
\text { be chosen in } \\
\text { collaboration with } \\
\text { upstream } \\
\text { activities. For }\end{array}$ & & & \\
\hline
\end{tabular}


heating instead of cooling, if heating is already

included in the

following

processing steps.

4. When total

consumption and

emissions are to

be quantified,

possibilities for

future up-cycling

of by-products

should be taken

into consideration.

5. When

upcycling by-

products include

water-saving and

pollution-

mitigation

technologies.

6. Treat process

water for by-

product

processing within

the process, in

order to:

-utilise product-

residues for

biogas and/or

animal feed

-reduce pollution

from the process

-reduce the need

for clean water

7. Adapt the

collection-

frequency for by-

products for

rendering

according to the

yearly seasons.

More frequent

collections in the

warmer periods

will limit bio-

degradation of

products and

malodour.

8. Apply heat-

reflecting

surfaces and well-

ventilated

cladding on by-

product silo

exterior, if sun-

exposed.

9. Reuse process-

water for cleaning

of wastewater

screens, if

appropriate water

quality is 


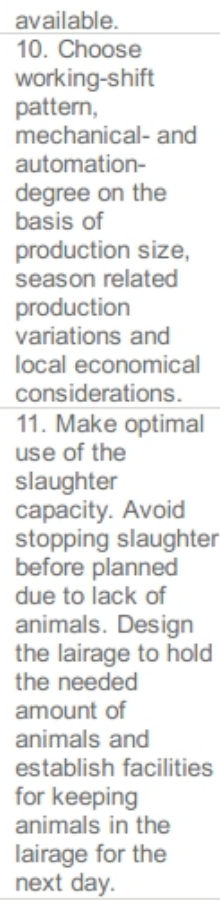

16. Potential new BAT for slaughterhouses (e.g. applied by your facility)?

-suggest any, or ideas, that can lead to new technologies and procedures that can result in reduction of consumptions and emissions.

\section{Following BATs are taken from the present BREF chapter}

5

Please mark the techniques "applied", "partially applied", or "not applied" at your facilities - if "not applied" please consider the applicability of the BAT, and mark "not applicable" if the BAT is not considered feasible comparing investment, running costs, savings, and environmental benefits on the basis of your production, plant size etc.

Definition of BAT Best Available Technique (taken from the IPPC directive):

Best: The most effective achieving of a high general level of protection of the environment as a whole.

Available: Available under economical and technical conditions, and (reasonably) accessible to the operator. 
Technique: Technology used and the way in which the installation is designed, built, maintained, operated and decommissioned.

\section{Current BREFs applied in your facility?}

If further information is needed, the slaughterhouse and producers of animal by-products BREF can be found through this link: http://eippcb.jrc.ec.europa.eu/reference/sa.html

\section{Which general slaughtering and by-product installation BATs are you applying in} your facility? (section 5.1.1)

Mark only one oval per row.

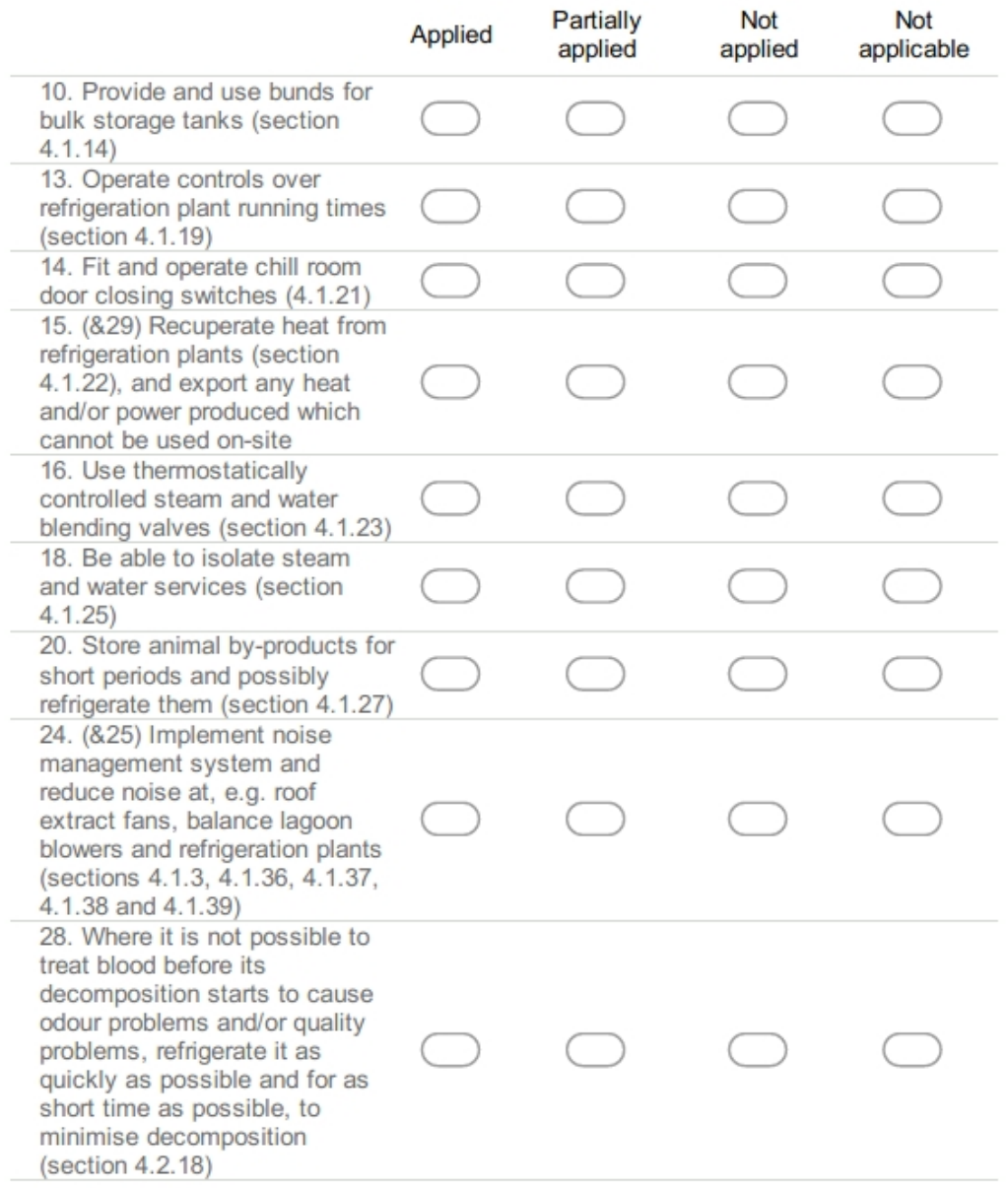


18. Which environmental management BAT's are you applying in your facility? (section 5.1.1)

Mark only one oval per row.

Environmental management
system - policy, procedures and
review of environmental
performance (section 5.1.1.1)
Evaluation of environmental
management system - by an
accredited body or external
verifier (section 5.1.1.1)
$\begin{aligned} & \text { Publication of a regular } \\ & \text { environmental statement of } \\ & \text { current and targeted aspects } \\ & \text { (section 5.1.1.1) }\end{aligned}$

19. Collaboration with upstream and downstream activities (section 5.1.3)

Mark only one oval per row.

\begin{tabular}{|c|c|c|c|c|}
\hline & Applied & $\begin{array}{l}\text { Partially } \\
\text { applied }\end{array}$ & $\begin{array}{c}\text { Not } \\
\text { applied }\end{array}$ & $\begin{array}{c}\text { Not } \\
\text { applicable }\end{array}$ \\
\hline $\begin{array}{l}\text { Seek collaboration with } \\
\text { upstream and downstream } \\
\text { partners, to create } \\
\text { environmental responsibility } \\
\text { (section } 5.1 .3 \text { ) }\end{array}$ & & & & \\
\hline
\end{tabular}

20. Installation and equipment cleaning BATs (section 5.1.4)

Mark only one oval per row.

\begin{tabular}{lccc} 
Applied & $\begin{array}{c}\text { Partially } \\
\text { applied }\end{array}$ & $\begin{array}{c}\text { Not } \\
\text { applied }\end{array}$ & $\begin{array}{c}\text { Not } \\
\text { applicable }\end{array}$ \\
\hline $\begin{array}{l}\text { 4. Where suitable, operate } \\
\text { cleaning-in-place (CIP) system } \\
\text { (section 4.2.4.3) }\end{array}$ &
\end{tabular}

21. Additional BAT for slaughterhouses (section 5.2)

Mark only one oval per row.

\begin{tabular}{|c|c|c|c|c|}
\hline & Applied & $\begin{array}{l}\text { Partially } \\
\text { applied }\end{array}$ & $\begin{array}{c}\text { Not } \\
\text { applied }\end{array}$ & $\begin{array}{c}\text { Not } \\
\text { applicable }\end{array}$ \\
\hline $\begin{array}{l}\text { 9\&10. Manage and monitor } \\
\text { compressed air and ventilation } \\
\text { use (sections } 4.2 .1 .19 \text { \& } \\
\text { 4.2.1.20) }\end{array}$ & & & & \\
\hline $\begin{array}{l}\text { 11. Use backward bowed } \\
\text { centrifugal fans in ventilation } \\
\text { and refrigeration systems } \\
\text { (section } 4.2 .1 .21 \text { ) }\end{array}$ & & & & \\
\hline
\end{tabular}


22. Additional BAT for slaughtering of large animals (cattle, pig, sheep and lamb) (section 5.2.1)

Mark only one oval per row.

1. Stop feeding animals 12
hours prior to slaughtering, and
minimising the animal's time in
slaughterhouse-lairage in order
to reduce manure production
(sections 4.2.2.1.1 \& 4.2.2.1.2)
6. Steam scald pigs (vertical
scalding) (section 4.2.2.3.1)
8\&12. Re-use cold water within
pig de-haining machines and
replace irrigation pipes with flat
jet nozzles (also for rind
treatment) (sections 4.2 .2 .4 .1$,
4.2.2.4.2 and 4.2.2.6.1)
9\&10. Re-use cooling water and
recover exhaust gas heat (to
pre-heat water) from pig
singeing kilns (section 4.2.2.5.1
\& 4.2.2.5.2)
13. Sterilise chest-opening
saws in a cabinet with
automated hot water nozzles
(section 4.2.2.7.1)
15. Use either water-spray/mist-
cooling or blast-chilling/shock-
cooling tunnel to cool pigs
(sections 4.2.2.8.1 \& 4.2.2.8.2)
-are you using batch cooling?
21. Use a mechanised fat trap
for removing fat from water
(section 4.2.2.9.7)

23. Additional BAT for the slaughter of poultry (section 5.2.2)

Mark only one oval per row.

1. Apply dust abatement at bird
reception, unloading and
hanging stations (sections
4.2.3.1.2, 4.2.3.1.3 and
4.2.3.1.4)
2. Stun birds in their modules,
using inert gases at new
installations and when existing
equipment and vehicles are due
for renewal (section 4.2 .3 .2 .1 )
4. Steam scald poultry (section
4.2.3.3.1)
9. Chill poultry by
immersion/spin chilling and to
control, regulate and minimise
the water consumption (section
4.2.3.6.2)


24. Other comments? 


\section{Appendix 3: By-products installation questionnaire}

\section{Questionnaire (for animal by-product industries)}

Project on Best Available Techniques (BAT) for Slaughterhouses and Animal By-products industries in the Nordic Countries.

${ }^{*}$ Required

1. Person answering/contact person? *

Name, contact information (mail, phone number) and company-affiliation.

2. Country where by-product facility is located?

Mark only one oval.

Finland

Denmark

Norway

Sweden

3. Address of the by-product facility?

-one facility per questionnaire.

4. Total operational capacity of the by-product facility?

Mark only one oval.

More or equal than 10 tons/day?

Less than 10 tons/day? 
5. By-product processed from which animal/s? Check all that apply.
Pig
Cattle
Poultry
Sheep and lamb
Fallen stock

Other:

6. Total yearly weight of animal by-products?

\section{What are the received by-products used for?}

8. What is your seasonal variation in production? -amount of operational weeks/year.

9. Amount of production days per operational week? Mark only one oval.

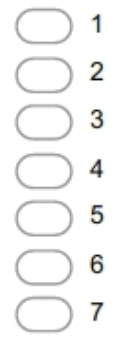


10. Number of work-shifts per day, at facility? Mark only one oval.
1
2
Other:

11. Which parameters are part of your ongoing operational control and how are these accounted?

Mark only one oval per row.

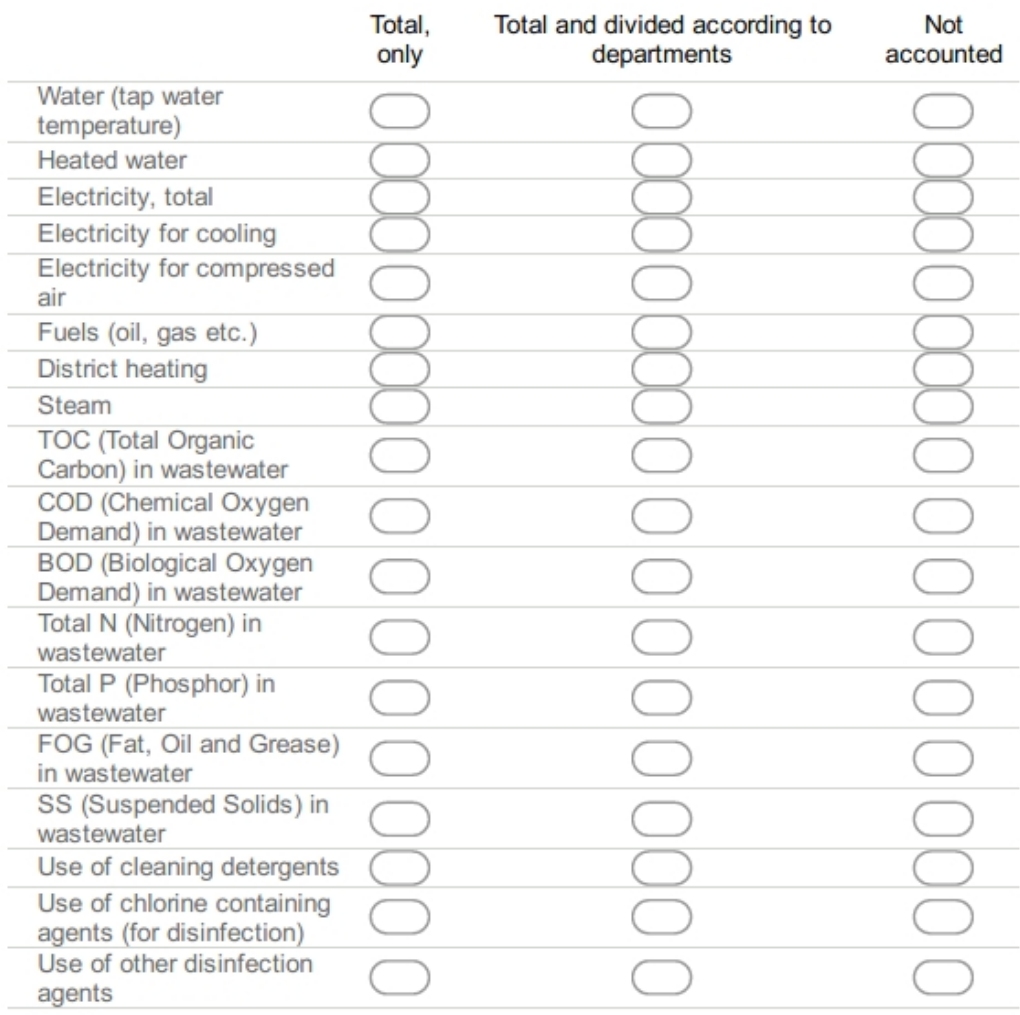

12. Which functional unit is used to evaluate facility consumption of resources over time?

(e.g. to justify increase in total resource consumption)

Check all that apply.

Raw materials (weight)

Finished products (weight)

Quality and weight of finished products (quality $\mathrm{x}$ weight)

Other: 
13. New or partially new suggested BATs - or usefull consideration in future work -relate to if these are suitable for your facility and sector in general.

Mark only one oval per row.

\begin{tabular}{|c|c|c|c|}
\hline & $\begin{array}{l}\text { Suitable (should } \\
\text { be introduced) }\end{array}$ & $\begin{array}{l}\text { Partially (should be } \\
\text { introduced with } \\
\text { modifications) }\end{array}$ & $\begin{array}{l}\text { Not suitable (not } \\
\text { to be introduced) }\end{array}$ \\
\hline $\begin{array}{l}\text { 1. Include life } \\
\text { cycle thinking, } \\
\text { when considering } \\
\text { sustainability of } \\
\text { methods, } \\
\text { processes and } \\
\text { product utilisation } \\
\text { - thus } \\
\text { environmental } \\
\text { burden shifting is } \\
\text { minimised. }\end{array}$ & & & \\
\hline $\begin{array}{l}\text { 2. Adapt the } \\
\text { collection- } \\
\text { frequency for by- } \\
\text { products } \\
\text { according to the } \\
\text { yearly seasons. } \\
\text { More frequent } \\
\text { collections in the } \\
\text { warmer periods } \\
\text { will limit bio- } \\
\text { degradation of } \\
\text { products and } \\
\text { malodour. Also, } \\
\text { avoid that } \\
\text { material is left for } \\
\text { next day } \\
\text { emptying. }\end{array}$ & & & \\
\hline $\begin{array}{l}\text { 3. Apply heat- } \\
\text { reflecting } \\
\text { surfaces and well- } \\
\text { ventilated } \\
\text { coatings on by- } \\
\text { product silo } \\
\text { exterior. }\end{array}$ & & & \\
\hline $\begin{array}{l}\text { 4. Choose } \\
\text { working-shift } \\
\text { pattern, } \\
\text { mechanical- and } \\
\text { automation- } \\
\text { degree on the } \\
\text { basis of } \\
\text { production size, } \\
\text { season related } \\
\text { production } \\
\text { variations and } \\
\text { local economical } \\
\text { considerations. }\end{array}$ & & & \\
\hline $\begin{array}{l}\text { 5. Collaborate } \\
\text { with downstream } \\
\text { activities } \\
\text { regarding } \\
\text { collection } \\
\text { frequency of raw } \\
\text { materials and, if } \\
\text { needed, } \\
\text { preservation of }\end{array}$ & & & \\
\hline
\end{tabular}




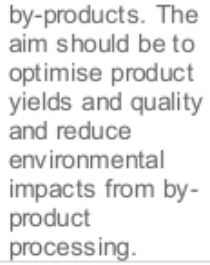

14. Potential new BAT for producers of animal by-products (e.g. applied by your facility)?

-suggest any, or ideas, that can lead to new technologies and procedures that can result in reduction of consumptions and emissions.

15. Other comments? 


\section{Appendix 4: Environmental permit writer questionnaire}

\section{Questionnaire (for environmental permit writers)}

Project on environmental indicators for Slaughterhouses and Producers of Animal Byproducts in the Nordic Countries.

* Required

1. Person answering/contact person? *

Name, company-affiliation, address and contact information (mail, phone number).

2. Country?

Mark only one oval.

Finland

Denmark

Norway

Sweden

\section{Environmental indicators?}

Which environmental indicators are used in your country when giving permits to - and monitoring environmental impacts from - slaughterhouses for pigs, cattle, poultry and sheep/lamb and by-products plants?

3. Slaughterhouses - use of resources?

e.g. drinking water, electricity, heating etc.? 
4. Slaughterhouses - emissions to air? e.g. $\mathrm{CO} 2, \mathrm{CO}, \mathrm{NOx}, \mathrm{SO} 2$, odur, noise etc.?

\section{Slaughterhouses - emissions to water?}

e.g. amount of wastewater, TOC, COD, BOD, N, P, BI5, SS, fat, pH, temperature etc.?

6. Slaughterhouses - emissions to soil?

e.g. metals, waste etc.?

7. Animal by-product plants (if not identical with slaughterhouses) - use of resources?

e.g. drinking water, electricity, heating etc.?

8. Animal by-product plants (if not identical with slaughterhouses) - emissions to air? e.g. $\mathrm{CO} 2, \mathrm{CO}, \mathrm{NOx}, \mathrm{SO} 2$, odur, noise etc.? 
9. Animal by-product plants (if not identical with slaughterhouses) - emissions to water?

e.g. amount of wastewater, $\mathrm{COD}, \mathrm{BOD}, \mathrm{N}, \mathrm{P}, \mathrm{BI} 5, \mathrm{SS}$, fat, $\mathrm{pH}$, temperature etc.?

10. Animal by-product plants (if not identical with slaughterhouses) - emissions to soil?

e.g. metals, waste etc.?

11. Other comments? 



\section{Appendix 5: Environmental permit writers answers}

Appendix table 2: Full answers and all stated environmental indicators that according to questioned environmental permit writers or environmental inspectors are used in selected Nordic countries when issuing permits to - and monitoring environmental impacts from slaughterhouses and by-products installations

\begin{tabular}{|c|c|c|c|c|c|c|c|c|c|}
\hline \multirow{5}{*}{$\begin{array}{l}\text { Emission } \\
\text { to /use of } \\
\text { materials }\end{array}$} & \multirow{5}{*}{$\begin{array}{l}\text { Environmental } \\
\text { indicator }\end{array}$} & \multicolumn{8}{|c|}{ Sectors / authorities } \\
\hline & & \multicolumn{4}{|c|}{ Slaughterhouses } & \multicolumn{4}{|c|}{ By-products installations } \\
\hline & & Answer \#1 & \#2\&3 & $\#_{4}$ & \#5 & Answer \#1 & \#2\&3 & $\#_{4}$ & $\#_{5}$ \\
\hline & & DK & SE & NO & FIN & DK & SE & No & FIN \\
\hline & & $E P W * / * *$ & $\mathrm{El} * *$ & EPW & EPW & EPW & EI & EPW & EPW \\
\hline
\end{tabular}

Water

$\begin{array}{lcccccccc}\text { Temp. } & \mathrm{x} & - & \mathrm{x} & \mathrm{x} & \mathrm{x} & - & \mathrm{x} & \mathrm{x} \\ \mathrm{pH} & \mathrm{x} & - & \mathrm{x} & \mathrm{x} & \mathrm{x} & - & \mathrm{x} & \mathrm{x} \\ \text { Total P } & \mathrm{x} & \mathrm{x} & \mathrm{x} & \mathrm{x} & \mathrm{x} & \mathrm{x} & - & \mathrm{x} \\ \text { Total N } & \mathrm{x} & \mathrm{x} & - & \mathrm{x} & \mathrm{x} & \mathrm{x} & - & \mathrm{x} \\ \text { BOD } & \mathrm{x} & \mathrm{x} & \mathrm{x} & \mathrm{x} & \mathrm{x} & \mathrm{x} & \mathrm{x} & \mathrm{x} \\ \text { COD } & \mathrm{x} & - & \mathrm{x} & \mathrm{x} & \mathrm{x} & - & - & \mathrm{x} \\ \text { SS } & \mathrm{x} & - & \mathrm{x} & \mathrm{x} & \mathrm{x} & - & \mathrm{x} & \mathrm{x} \\ \text { Fat } & - & - & \mathrm{x} & \mathrm{x} & \mathrm{x} & - & \mathrm{x} & \mathrm{x} \\ \text { Blood } & - & - & \mathrm{x} & - & - & - & \mathrm{x} & - \\ \text { Metals } & - & \mathrm{x} & - & - & - & \mathrm{x} & - & - \\ \text { Disinfectants \& } & - & - & - & - & - & - & \mathrm{x} & - \\ \text { detergents } & & & & & & & & \end{array}$

Air

$\begin{array}{lllllllll}\mathrm{CO} & \mathrm{x} & - & \mathrm{x} & - & \mathrm{x} & - & \mathrm{x} & - \\ \mathrm{NO}_{x} & \mathrm{x} & \mathrm{x} & \mathrm{x} & \mathrm{x} & \mathrm{x} & - & \mathrm{x} & \mathrm{x} \\ \mathrm{NH}_{3} & - & - & - & \mathrm{x} & \mathrm{x} & - & - & \mathrm{x} \\ \mathrm{SO}_{2} & \mathrm{x} & - & \mathrm{x} & \mathrm{x} & \mathrm{x} & - & \mathrm{x} & \mathrm{x} \\ \mathrm{H}_{2} \mathrm{~S} & - & - & - & \mathrm{x} & \mathrm{x} & - & - & \mathrm{x} \\ \mathrm{TOC} & - & - & - & - & \mathrm{x} & - & - & - \\ \mathrm{HCl} & - & - & - & - & \mathrm{x} & - & - & -\end{array}$




\begin{tabular}{|c|c|c|c|c|c|c|c|c|c|}
\hline \multirow{11}{*}{$\begin{array}{l}\text { Emission } \\
\text { to /use of } \\
\text { materials }\end{array}$} & \multirow{5}{*}{$\begin{array}{l}\text { Environmental } \\
\text { indicator }\end{array}$} & \multicolumn{8}{|c|}{ Sectors / authorities } \\
\hline & & \multicolumn{4}{|c|}{ Slaughterhouses } & \multicolumn{4}{|c|}{ By-products installations } \\
\hline & & $\begin{array}{c}\text { Answer } \\
\# 1\end{array}$ & $\# 2 \& 3$ & $\# 4$ & $\# 5$ & $\begin{array}{c}\text { Answer } \\
\#_{1}\end{array}$ & $\# 283$ & \#4 & $\# 5$ \\
\hline & & DK & SE & NO & FIN & DK & SE & No & FIN \\
\hline & & $E P W * I * *$ & $\mathrm{El} * *$ & EPW & EPW & EPW & EI & EPW & EPW \\
\hline & $\mathrm{Hg}$ & $x$ & - & - & - & $x$ & - & - & - \\
\hline & Sum of $\mathrm{Ni}, \mathrm{V}, \mathrm{Cr}, \mathrm{Cu}, \mathrm{Pb}$ & $x$ & - & $x$ & - & $x$ & - & $x$ & - \\
\hline & Dioxin/furan & $x$ & - & - & - & $x$ & - & - & - \\
\hline & Dust $(<10 \mu \mathrm{m})$ & $x$ & - & $x$ & - & $x$ & - & $x$ & - \\
\hline & $\mathrm{Zn}$ & - & - & - & - & $x$ & - & - & - \\
\hline & $\mathrm{Cd}$ & - & - & - & - & $x$ & - & - & - \\
\hline
\end{tabular}

Soil

$\begin{array}{lllllllll}\begin{array}{l}\text { Spill of chemicals \& } \\ \text { products (e.g. oil, salt) }\end{array} & \text { X } & - & \text { X } & - & \text { X } & - & \text { X } & \text { - } \\ \text { Heating } & \text { X } & \text { X } & \text { X } & \text { X } & - & \text { X } & \text { X } & \text { X } \\ \text { Chemicals } & \text { X } & \text { X } & \text { X } & - & \text { X } & \text { X } & \text { X } & \text { X }\end{array}$

Nuisances

$\begin{array}{lllllllll}\text { Noise } & x & x & x & x & x & x & x & x \\ \text { Odour } & x & x & x & x & x & x & x & x\end{array}$

Resources use

\begin{tabular}{|c|c|c|c|c|c|c|c|}
\hline Drinking water & $x$ & $x$ & $x$ & $x$ & - & $x$ & $x$ \\
\hline Electricity & $x$ & $x$ & $x$ & $x$ & - & $x$ & $x$ \\
\hline Heating & $x$ & $x$ & $x$ & $x$ & - & $x$ & $x$ \\
\hline Chemicals & $x$ & $x$ & $x$ & - & $x$ & $x$ & $x$ \\
\hline
\end{tabular}

Waste

management

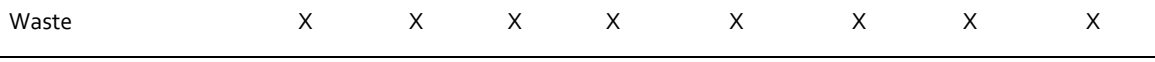

Note: * Only direct water emission is considered, as the indirect emissions are handled by local authorities. ** EPW=Environmental Permit Writers, El=Environmental Inspectors 
Nordic Council of Ministers

Ved Stranden 18

DK-1061 Copenhagen K

www.norden.org

\section{Slaughterhouses and producers of Animal By-products in the Nordic Countries}

The Nordic Council of Ministers, the BAT-group under Working Group for Sustainable Consumption and Production, has awarded Danish Meat Research Institute (DMRI) to deliver a review report on Best Available Techniques (BAT) for slaughterhouses and producers of animal by-products in relation to the Nordic industry. The intention with the report is to use it in the first step of the upcoming EU revision of a new slaughterhouse and animal by-products BAT-reference document (BREF). The project is based on questionnaires in which slaughterhouses and animal by-products industries from Denmark, Sweden, Norway and Finland were asked about their current production patterns, emissions and resource accounting, and relation to potentially dubious BATs (BATs that may be difficult to follow). 